\title{
Tumor necrosis factor during sepsis : king of cytokines?
}

Citation for published version (APA):

Engelberts, I. (1994). Tumor necrosis factor during sepsis : king of cytokines? [Doctoral Thesis, Maastricht University]. Datawyse / Universitaire Pers Maastricht. https://doi.org/10.26481/dis.19940617ie

Document status and date:

Published: 01/01/1994

DOI:

10.26481/dis.19940617ie

Document Version:

Publisher's PDF, also known as Version of record

\section{Please check the document version of this publication:}

- A submitted manuscript is the version of the article upon submission and before peer-review. There can be important differences between the submitted version and the official published version of record.

People interested in the research are advised to contact the author for the final version of the publication, or visit the DOI to the publisher's website.

- The final author version and the galley proof are versions of the publication after peer review.

- The final published version features the final layout of the paper including the volume, issue and page numbers.

Link to publication

\footnotetext{
General rights rights.

- You may freely distribute the URL identifying the publication in the public portal. please follow below link for the End User Agreement:

www.umlib.nl/taverne-license

Take down policy

If you believe that this document breaches copyright please contact us at:

repository@maastrichtuniversity.nl

providing details and we will investigate your claim.
}

Copyright and moral rights for the publications made accessible in the public portal are retained by the authors and/or other copyright owners and it is a condition of accessing publications that users recognise and abide by the legal requirements associated with these

- Users may download and print one copy of any publication from the public portal for the purpose of private study or research.

- You may not further distribute the material or use it for any profit-making activity or commercial gain

If the publication is distributed under the terms of Article $25 \mathrm{fa}$ of the Dutch Copyright Act, indicated by the "Taverne" license above, 


\title{
TUMOR NECROSIS FACTOR DURING SEPSIS
}

\author{
KING OF CYTOKINES ?
}


Cover: Until now, efforts to repress the cytokine cascade in SIRS patients with TNF-blocking agents only showed. the incessant force of the cytokine system.

Photo: W. Engeiberts \& E. Schins 


\title{
TUMOR NECROSIS FACTOR DURING SEPSIS
}

\section{KING OF CYTOKINES ?}

\author{
PROEFSCHRIFT \\ ter verkrijging van de graad van doctor \\ aan de Rijksuniversiteit Limburg te Maastricht, \\ op gezag van de Rector Magnificus, Prof. dr. H. Philipsen, \\ volgens het besluit van het College van Decanen, \\ in het openbaar te verdedigen \\ op vrijdag 17 juni 1994 om 16.00 uur
}

door

\section{Ingeborg Engelberts}

geboren te Den Haag, 31 mei 1963

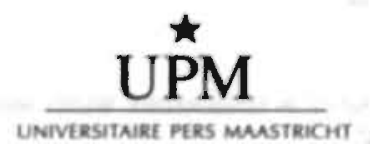




\section{Promotores}

Prof. dr. G. Kootstra

Prof. dr. C.J. van der Linden (Katholieke Universiteit Nijmegen)

\section{Co-promotor}

Dr. W.A. Buurman

\section{Beoordelingscoimmissie}

Prof. dr. E.F.M. Wouters (voorzitter)

Prof. dr. R.J.A. Goris (Katholieke Universiteit Nijmegen)

Prof. dr. J.P. van Hooff

Prof. dr. S. de Lange

Prof. dr. L.G. Thijs (Vrije Universiteit Amsterdam)

CIP-DATA KONINKLIJKE BIBLIOTHEEK, DEN HAAG

Engelberts, Ingeborg

Tumor necrosis factor during sepsis : king of cytokines? /

Ingeborg Engelberts. - Maastricht: Universitaire Pers

Maastricht. -Ill.

Thesis Maastricht. - With ref. - With summary in Dutch.

ISBN 90-5278-146-X

Subject headings: tumor necrosis factor / cytokines /

sepsis.

Layout: Karin Scheele, A Point, Maastricht

Production: Datawyse, Maastricht

HET IN DIT PROEFSCHRIFT BESCHREVEN ONDERZOEK WERD MEDE FINANCIEEL MOGELUK, GEMAAKT DOOR "HET PRAEVENTIE FONDS", 
Wij moeten het idee opgeven van de witeindelifke bronnen van onze kennis en erkennen dat alle kennis menselijk is.

Deze is vermengd met onze fouten en onze woonoondelen.

De waarheid gaat de menselijke kennis to boven.

(Popper) 



\section{ABBREVIATIONS USED}

$\begin{array}{ll}\text { ARDS } & \text { adult respiratory distress syndrome } \\ \text { BCG } & \text { bacillus Calmette Guérin } \\ \text { ELAM-1 } & \text { endothelial leukocyte adhesion molecule-1 } \\ \text { ELISA } & \begin{array}{l}\text { enzyme-linked immunosorbent assay } \\ \text { human }\end{array} \\ \text { h } & \text { intensive care unit } \\ \text { ICU } & \text { interferon } \\ \text { IFN } & \text { interleukin } \\ \text { IL } & \text { LPS-binding protein } \\ \text { LBP } & \text { lethal dose } \\ \text { LD } & \text { lipopolysaccharide } \\ \text { LPS } & \text { major histocompatibility complex } \\ \text { MHC } & \text { multiple organ dysfunction syndrome } \\ \text { MODS } & \text { multiple organ failure } \\ \text { MOF } & \text { platelet activating factor } \\ \text { PAF } & \text { prostaglandin } \\ \text { PG } & \text { recombinant } \\ r & \text { radio immuno assay } \\ \text { RIA } & \text { systernic inflammatory response syndrome } \\ \text { SIRS } & \text { tumor necrosis factor- } \alpha \\ \text { TNF } & \end{array}$




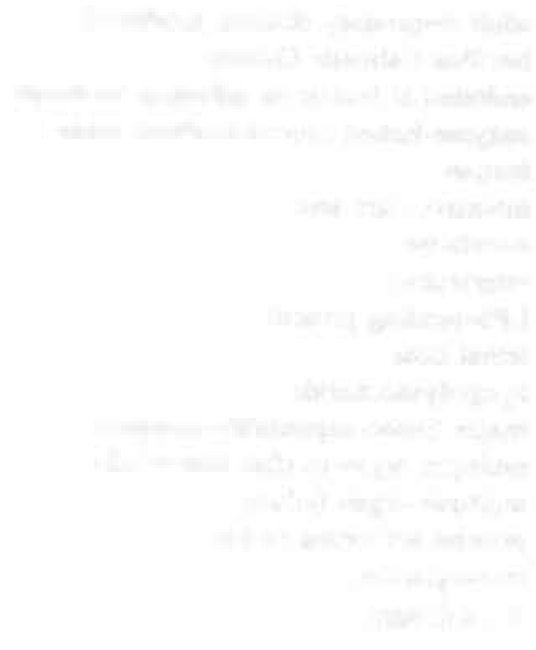




\section{CONTENTS}

Chapter 1 GENERAL INTRODUCTION II

Definition of sepsis 11

Sepsis, a problem of major importance $\mathbf{i}$

$\begin{array}{ll}\text { Pathogenesis of the systemic inflammatory response } & 12\end{array}$

Identification of the endogenous mediators which are

involved in pathogenesis of septic shock 13

TNF, member of the cytokine family 14

Control of the TNF signal 15

Role of TNF in the defense against infections 16

$\begin{array}{ll}\text { Metabolic changes induced by TNF } & 17\end{array}$

Involvement of TNF in pathogenesis of disease 18

$\begin{array}{ll}\text { Conclusions } & 20\end{array}$

Chapter 2 DISCUSSION OF THE EXPERIMENTAL WORK 21

REFERENCES CHAPTERS I AND 2

SUMMARY OF THE THESIS $\quad 47$

SAMENVATTING VAN HET PROEFSCHRIFT 51

LIST OF PUBLICATIONS UNDEIRLYING THIS THESIS 55

$\begin{array}{ll}\text { DANKWOORD } & 57\end{array}$

$\begin{array}{lr}\text { CURRICULUM VITAE } & 59\end{array}$ 



\section{CHAPTER 1}

\section{GENERAL INTRODUCTION}

\section{Definition of sepsis}

Initially, the term sepsis has been assigned for the process of multiplication of microorganisms in the bloodstream, which often is accompanied by a systemic inflammatory response. Positive blood cultures have traditionally been considered to be essential for the diagnosis of sepsis. But the frequent occurrence of a systemic inflammatory response without being able to demonstrate the presence of microorganisms or their toxins in the circulation [1] has caused that early diagnosis is usually made on clinical grounds. These considerations incited the American College of Chest Physicians/Society of Critical Care Medicine (ACCP/SCCM) to recommend new definitions for the syndrome of sepsis in terms of its clinical manifestations [2].

Also serious diseases which are accompanied by extensive tissue necrosis, such as multiple trauma, massive gastrointestinal tract bleeding, pancreatitis or large burns may cause an identical systemic inflammatory state in the absence of infection [3-6]. It is likelly that the pathogenesis of the infectious and non-infectious inflammatory response. are similar. The term systemic inflarnmatory response syndrome (SIRS) has therefore been proposed by the ACCP/SCCM to describe this generalized inflammatory reaction, independent of its cause. Patients suffering from the systemic inflammatory response syndrome should meet two or more of the following clinical criteria: (1) temperature $>38^{\circ} \mathrm{C}$ or $\left\langle 36^{\circ} \mathrm{C}\right.$; (2) heart rate $>90$ beats per minute; (3) respiratory rate $>20$ breaths per minute or $\mathrm{PaCO}_{2}<32 \mathrm{mmHg}$; and (4) white blood cell count $>12.10^{-6} \mathrm{~T}^{-1}$ or $\left\langle 4.10^{-9} \mathrm{~T}^{-1}\right.$, or $>10 \%$ immature neutrophils [2]. Severe SIRS is associated with perfusion abnormalities as appears from lactic acidosis, oliguria and acute alteration of mental state. Sepsis, finally, has been defined as the subgroup of SIRS which is initiated by invasive microorganisms [2].

In spite of the fact that the use of the term SIRS demonstrates insight into the pathogenesis of sepsis, this term still is not widely used in literature. Therefore, in the text below, the term sepsis will not be utilized as a subgroup of SIRS, but as an equivalent to it, similar to the use in current literature.

\section{Sepsis, a problem of major importance}

The incidence of SIRS has been reported to be 7-28 of all 1000 hospitalized patients [79]. While its incidence is growing [10] and its severity is increasing [7], SIRS now is 
the major cause of death in the surgical intensive care unit (ICU). This is thought to be a consequence of the tendency to treat patients at older age and an later stages of disease $[7,9,10]$, concurrent with increasing use of invasive devices for diagnosis and therapy [11]. The microorganisms that cause SIRS most cornmonly have been gram-negative bacteria [7]. However, gram-positive cocci have re-emerged as the leading cause of hospital acquired infections most commonly related to intravascular devices [12], especially in immunocompromised patients $[9,10]$.

Several clinical studies demonstrated that the major threat to survival of SIRS is not the underlying disease, but rather the development of organ system dysfunction, including acute lung failure and shock. Hypotension occurs in $44-59 \%$ of septic patients, which worsens prognosis from $7-13 \%$ mortality in patients with uncomplicated sepsis to 28 $47 \%$ in patients with septic shock $[13,14]$. The term multiple organ failure (MOF) or multiple organ dysfunction syndrome (MODS) is used to describe the development of progressive organ dysfunction [2].

The severity of organ dysfunction varies from patient to patient. Until now, it has not been possible to predict which patient with SIRS will develop MODS or to predict the severity and outcome of SIRS. Bacterial cultures and etiology of SIRS appears not to be the only factors which determine the severity of the disease [4, 7, 13-15]. For an effective use of medical resources, it is important to find criteria which identify patients in early stages of SIRS who are at greatest risk to develop organ failure. A correlation exists between the patient's constitution and the risk of developing complications of SIRS, as reflected in ICU survival rates $[10,14,16]$. So the APACHE III prognostic scoring system for mortality risk of critically ill patients includes criteria which estimate co-morbidity, chronic health condition and physiologic age [17].

\section{Pathogenesis of the systemic inflammatory response syndrome}

Early research on pathogenesis of septic shock did already show that sera from septic patients effectively transmit manifestations of the septic response [18].This pointed to the involvement of circulating factors in the mediation of the systemic inflammatory response syndrome. In 1944 the activity of lipopolysaccharide (LPS or endotoxin) has been identified in the mediation of lethal shock and tissue injury [19]. LPS which is a component of the cell-wall of gram-negative bacteria, is liberated amply into the circulation during gram-negative bacterial breakdown [20]. This condition is called endotoxemia.

Experimental administration of sterile L.PS to animals and humans is sufficient for the induction of a complete septic response, characterized by fever, hyperdynarnic shock and respiratory stimulation [19]. L.PS activates both the complement [21] and the coagulation systems [22]. Triggering of the intrinsic and the extrinsic coagulation system by L.PS is considered to participate in diffuse intravascular coagulation during endotoxin shock 
[22]. Activation of the complement system by LPS explains the depressed serum levels of complement proteins [23] and the elevated plasma levels of the cleavage fragments $\mathrm{C} 3 \mathrm{a}$ and $\mathrm{C} 4 \mathrm{a}$, which are observed during sepsis [24]. The cleavage fragments cause vasodilatation [25] and increased vascular permeability due to endothelial cell damage [26]. Both events are important for induction of shock during sepsis. In addition to their effects on the vessel wall, complement products have diverse activating effects on neutrophils, such as aggregation and adhesion to the vascular endothelium [27], stimulation of arachidonate metabolism [28, 29] and platelet activating factor (PAF) production [30], generation of toxic oxygen radicals $[26,31]$ and release of lysosomal enzymes [31]. If these processes occur in the lung, plasma can escape into the interstitial spaces. and the alveoli, a situation characteristic for the adult respiratory distress syndrome (ARDS).

Because circulating L.PS predicts poor outcome of disease [32], it has been thought for a long time that the amount of LPS which is released into the circulation is the major determinant of the magnitude of the systemic inflammatory response and of the occurrence of complications. However, the extent of the inflammatory response in answer to a comparable bacterial load varies greatly between patients [33]. This does not fit in with the assumption that the extent of LPS-release into the circulation determines the severity of disease. In addition, induction of the systemic inflammatory response is not unique for LPS: a variety of microbial products, including those from gram-positive organisms $[12,34]$ can elicit pathophysiological responses similar to SIRS. The fact that SIRS can even develop in absence of invasive microorganisms [3-6] shows that infectious agents or microbial products cannot primarily be the determinant of the systemic inflammatory response. The realization that infectious and non-infectious septic responses are regulated at a mutual level independent from microorganisms, contributed to the insight that a second messenger system of endogenous mediators must exist which determines the course of this critical disease.

\section{Identification of the endogenous mediators which are Involved in the pathogenesis of septic shock}

A spontaneous mutation in $\mathrm{C} 3 \mathrm{H} / \mathrm{HeJ}$ mice rendered this strain of mice hyposensitive to LPS [35]. This gave the opportunity to investigate the second messenger system for LPS. Bone marrow obtained frorn LPS-sensitive mice and which was made selectively deficient for B cells or T cells could completely restore reactivity to LPS after transplantation into $\mathrm{C} 3 \mathrm{H} / \mathrm{HeJ}$ mice [36]. It has therefore been concluded that lack of sensitivity to LPS in $\mathrm{C} 3 \mathrm{H} / \mathrm{HeJ}$ mice is determined by the function of the macrophage system. A large number of macrophage products have subsequently been described which are released in response to LPS stimulation.

Carswell and Old isolated a serum factor, produced by LPS-stimulated murine macrophages which causes hemorrhagic necrosis of experimental sarcomas in BCG- 
pretreated mice [37]. This factor was called rumor necrosis factor (TNF) [37]. This potential anti-tumor agent subsequently was isolated in the human form [38] and cloned [39]. As a result, TNF was recognized to be identical to cachectin [40], the recently sequenced endogenous humoral mediator that has been hold responsible for cachexia accompanying chronic infections [41, 42]. TNF became available in recombinant ( $r$ ) form [39] and in vivo and in vitro studies of the pleiotropic biological effects of TNF were periormed. Expectations ran high concerning the first therapeutic administrations of rTNF to cancer patients [43]. But TNF appeared to be an extremely toxic polypeptide which induces nearly every characteristic of septic shock after intravenous administration [43-45]. Therefore, the clinical applicability of RTNF as an anti-tumor agent is restricted. Toxicity, however, can be reduced when the drug is administered locoregionally [46]. By this remedy it is possible to reach higher concentrations of the drug while limiting toxicity [46]. For various distinct indications, administration of adjuvant RTNF during regional perfusion therapy may induce a favorable tumor response [47].

In addition to these observations, neutralizing anti-TNF antibodies appeared to protect against LPS-induced shock in mice [48] and E. coli-induced sepsis in baboons [49]. Therefore it was proposed that TNF may be the macrophage derived second messenger which determines the severify of systemic inflammation. LPS-stimulated macrophages from LPS-hyposensitive $\mathrm{C} 3 \mathrm{H} / \mathrm{He}$ mice are indeed defective in TNF production [50].

\section{TNF, member of the cytokine family}

TNF is a polypeptide which belongs to the large family of iytokines. Cytokines are polypeptide cell regulators, produced by cells of the immune system as well as by a numbet of other cell types [51]. Cytokines participate in a large variety of physiological processes, but they all affect in some way the function of the immune system [51] and have the common ability to act as communication signals [52]. Cytokine action is effectuated via binding to specific cell receptors and can be autocrine, paracrine or heterocrine. Basal production of cytokines is low or absent, but following certain inflammatory stimuli, massive responses may occur [53].

Characteristic for this group of humoral mediators is that cytokines function in a cytokine network, which implicates that the final response depends on the presence of other cytokines [54]. This is the result of three distinct mechanisms which modulate cytokine effects: 1) the individual members of the cytokine family have parly everlapping additive or synergistic functions, but may also be antagonistic, 2) cytokines stimulate or depress the production of other humoral inflammatory mediators, as a result of which cytokine action can be partially indirect and 3) the level of cytokine receptor expression can be either up-, or down regulated by the presence of other cytokines. 


\section{Control of the TNF signal}

Overproduction of TNF is considered to be important for the pathogenesis of shock and tissue injury during SIRS. It is therefore important to understand the factors which regulate its production. Cells from the monocyte/macrophage lineage are the main producers of TNF [55, 56], but also other leukocytes such as T-cells [57], natural killer (NK) cells [58] and neutrophils [59] can be specifically stimulated to secrete TNF. In the light of the involvement of TNF in the pathogenesis of sepsis, TNF production by monocytes is most likely induced by products of bacteria, parasites [60] and yeasts [61]. LPS has been most intensively studied out of these. Many different binding sites for LPS on the cell surface of macrophages have been described [62-64]. LPS can interact with the monocytic cell membrane CD14 receptor after binding to the acute phase protein LPS-binding protein LBP $[64,65]$. The LPS-LBP complexes stimulate TNF production at much lower concentrations than those required for LPS alone [64, 65].

Also various mechanisms of TNF induction exist which do not involve microbial components. Diverse stimuli such as C5a [66], adherence of human monocytes [67], crosslinking of Fc-gamma receptors on monocytes [68], and exposure to ionizing radiation [69] all can induce TNF. Such stimuli may be important for the induction of TNF release during a non-infectious inflammatory response.

Production of TNF can be enhanced by various inflammatory mediators, including IFN (interferon)-gamma which is released by activated $\mathrm{T}$-cells during non-infectious inflammatory disease $[70,71]$, interleukin 1 (IL-1), a cytokine which shares many biological activities: with TNF [70], and reactive oxygen species which are ubiquitously present during inflammation [72]. Pretreatment of monocytes with LPS influences their TNF release in either a positive or a negative way, depending on experimental conditions [73]. A number of anti-inflammatory agents, such as glucocorticosteroids [50, 74], pentoxifylline $[74,75]$ and PAF-antagonists [76] are capable of suppressing the TNF signal. Fish oil consumption affects TVF responsiveness $[79,80]$, which is considered to be important for the anti-inflammatory effects caused by dietary fish oil [77, 78]. Also metabolites of the arachidonic acid cascade alter TNF gene transcription: cyclooxygenase products, including prostaglandin $(\mathrm{PG}) \mathrm{E}_{2}$, inhibit transcription of the gene [81], whereas lipoxygenase products increase TNF mRNA levels [82]. On the other hand, TNF is capable of activating the cyclooxygenase pathway thus inducing $\mathrm{PGE}_{2}[83]$ and $\mathrm{PGI}_{2}$ [84] production. As a result, cyclooxygenase products mediate part of the TNF effects [85]. The anti-inflammatory effects of cyclooxygenase inhibitors during TNF-mediated disease is considered to be a result of opposing TNF-induced cyclooxygenase activation $[85,86]$.

In addition to these exogenous influences on TNF secretion, several endogenous factors which determine TNF responsiveness have been identified. Stable interindividual differences in TNF secretory ability [87] are caused by differences in genetic control, as evidenced by different TNF genotypes [88]. The endocrine system affects the LPS- 
induced TNF response via the hypophysis-adrenal axis: TNF release is enhanced in absence of endogenous steroids [89]. The circadian fluctuation of TNF secretory capacity of in vitro stimulated whole blood, however, seems to be related to the thythrnical release of epiphysial melatonin in favor of hypophysial ACTH [90].

Although knowledge of the mechanisms which control TNF release and action is becoming increasingly detailed, the mechanisms which downregulate the signal have been obscure for al long time. Observations made in animals and humans indicate that strong feedback mechanisms exist for TNF, because half live of serum TNF after systemic administration of bolus LPS is shon [91]. Even during continuous intravenous adminisIration of rTNF, serum TNF rapidly becomes undetectable [92]. It has recently been proposed that circulating soluble TNF receptors may be a down regulating mechanism for TNF [93]. Two types of human soluble TNF receptors have been identified with 55-kDa and 75-kDa molecular weight [94]. Soluble TNF receptors are derived by proteolytic cleavage of membrane TNF receptors from activated target cells [95]. They specifically bind and inhibit TNF [96]. Serum TNF receptor levels raise upon systemic triggering of TNF receptor bearing cells, as has been demonstrated in serum from febrile patients [97], cancer patients treated with rTNF [98] and during experimental endotoxemia [99, 100]. Because soluble TNF receptor plasma levels are increased at moments which are prone for TNF release into the circulation, soluble TNF receptors may serve very well as scavengers for circulating free TNF.

\section{Role of TNF in the defense against infections}

Aifter cloning the gene for human TNF [39], the gene has been sequenced from a variety of other mammalian species, including mice [101], guinea pigs [102] and pigs [103]. A strikingly high interspecies homology has been observed every time. This strong conservation of genetic information for TNF during mammalian evolution points to the existence of an advantageous role of TNF for the host, although most effects of TNF release have been recognized in a pathophysiological context. Because TNF potently induces many aspects of inflammatory and immune reactions, TNF is thought to have its most beneficial role in the defense against infection. The indispensability of an intact TNF response for proper defense has been elegantly demonstrated in several experimental pathological conditions in mice: passive irnmunization against TNF enhances mortality during murine peritonitis [104] and exacerbates iisteriosis [105]. Administration of rTNF, on the other hand, can limit experimental infection with malaria parasites [106].

TNF activates inflammatory functions of various immune cells, not only as a direct effector, but also as part of the network of cytokines and other mediators. Synergistic interactions between TNF and IL $1[184,85,107-109]$. IFN-gamma $[70,71,110]$ and LPS [111] have been demonstrated. TNF further interacts with the complement system 
[112] and induces the additional release of eicosanoid mediators [83, 84], including PAF [113], by which TNF extends and amplifies its biological effects.

Membrane receptors for TNF are expressed on a wide variety of cells [114], indicating that many different sorts of cells are involved in the generation of TNF effects. TNF stimulates neutrophils to enhance their cytotoxicity [115], degranulation [116] and release of oxygen radicals [116, 117]. TNF increases complement receptor 1 and complement receptor 3 (CD11b/CDI8) expression on neutrophils [118]. Both receptors contribute to phagocytosis, whereas the latter is additionally involved in neutrophil adhesion, aggregation and migration [119]. Macrophages are stimulated to produce cytotoxic products [120]. Growth and differentiation of B [121] and T-cell [122] can be modestly influenced by TNF, although most of the effects of TNF on lymphocyte function are indirect. Further evidence for the involvement of TNF in mediating cellular immunity has been obtained by showing that MHC class I antigen expression is upregulated by TNF, mainly by augmenting the effects of IFN- $B_{1}$ [123].

In vitro experiments have shown that TNF has important activities on endothelial cells. TNF stimulates endothelial cells to release chemotactic proteins $[124,125]$ and to enhance the adherence of leukocytes to endothelium due to the effects on leukocytes and on endothelial cells. [reviewed in 126]. In addition, TNF stimulates the production of agents with significant vasodilative potency such as $\mathrm{PGI}_{2}$ [84] and nitric oxide [127]. Finally, TNF enables endothelial cells to express procoagulant activity [128] and to reduce endothelial fibrinolytic potential [129] which both contribute to a shift from anticoagulant activity to a procoagulant state.

TNF also has diverse effects which can help in the defense against non-bacterial pathogens. TNF has antiviral activity by its ability to eliminate virus-infected cells and to induce resistance to virus infection in diverse cell types [130, 131]. TNF enhances neutrophil toxicity against Candida albicans [132]. Macrophage killing of various parasites, including leishmania [133], trypanosoma cruzi [134] and malaria species [135] is augmented by TNF. Because TNF production can be induced by various sorts of parasites [60], TNF is considered to be important for host defense during parasitic infection. This has been confirmed by the demonstration that in mice, RTNF limits leishmaniasis infection [136] and protects against malaria [106], whereas anti-TNF enhances plasmodium parasitemia [137].

\section{Metabolic changes induced by TNF}

TNF induces prominent metabolic abnormalities which parallel the catabolic state which accompanies cancer and infectious disease [40, 42]. TNF alters lipid metabolism which results in hyperlipidemia [138, 139]. TNF inhibits lipid uptake in adipose tissue by decreasing lipoprotein lipase expression [41]. TNF enhances lipogenesis in the liver [140] which additionally contributes to the elevated plasma triglyceride levels. 
TNF-induced changes in protein metabolism result in a ioss of total-body nitrogen [138, 139, 141, 142]. This is probably because TNF administration causes an efflux of amino acids from skeletal muscle [138, 139, 141, 142], although direct effects of TNF on myocytes could not be demonstrated [143]. In contrast to the effects on protein metabolism in skeletal muscle, proteolysis in the liver is decreased [142] and hepatic acute phase protein synthesis is increased [144] in animals chronically exposed to TNF.

Also glucose metabolism is impaired following TNF administration, leading to a sharp decline in blood glucose levels to lethal values [86]. Apart from these peripheral effects, TNF acts directly on the brain to cause anorexia [145], fever [107] and an altered regulation of hypothalamic/pituitary hormones [146].

Several of the metabolic effects induced by TNF may contribute to the defense against invading microorganisms. Fever may potentiate immune activity, because certain immune responses are augmented at $39.5 \mathrm{C}$ [147]. Acute phase proteins such as $\mathbf{C}$ reactive protein can function as an opsonin and help with the clearance of pathogens [148]. Increased leve!s of lipoproteins may be important for binding [149] and detoxifying LPS [i50].

\section{Involvement of TNF in the pathogenesis of disease}

In vivo studies on the toxicity of TNF indicate that the mode of administration has important impact on its final biological effect. TNF, although important for host defense at low concentrations [151], induces pathology when overproduced [152]. Therefore, the amount of liberated TNF is one of the factors which determines the final biological response. The site of administration also has qualitative consequences for the biological effects of TNF [154]. The kinetics of administration, by the possibility to induce tolerance against TNF [153] and the local presence of additional humoral mediators [54, 109. 111] are factors which quantitatively affect the outcome of exposure to TNF [reviewed in 152]. The large variability of the TNF effects permitted the consideration that TNF is involved in the pathogenesis of a wide diversity of acute and chronic diseases.

Three lines of evidence demonstrate the involvement of TNF in the pathogenesis of shock and tissue injury during SIRS. First, intravenous administration of RTNF indeces a disease state which closely resembles septic shock accompanied by tissue injury [44. 45. 92]. TNF induces fever [107], leukocyte aggregation, hypotension, metabolic acidosis, stress hormone release [92]. lung edema and hemonhagic necrosis of various organs $[44,45]$. Second, the cylokine is released early ard in large arnounts in response to a wide variety of bacterial stimuli in experimental situations [49, 91, 155-157]. Also in patients with SIRS, presence of circulating TNF has been demonstrated [158-160], although controversies exist concerning the amount of circulating TNF, the number of patients with positive blood samples and the correlation between TNF plasma levels and 
outcome of disease. The thind and most important argument in favor of the central role of TNF in the mediation of the generalized inflammatory response is the repetitive demonstration that pretreatment with anti-TNF antibodies prevents mortality [48] and organ damage $[49,155]$ from experimental sepsis.

Notwithstanding these convincing arguments, various unexplained observations indicate that there is no plain cause-effect relationship between TNF release and the development of septic shock. In the same experimental models for sepsis in which pretreatment with anti-TNF is protective, intervention is not successful if the anti-TNF antibodies are given together or after elicitation of disease [48, 49]. TNF-blocking agents can even enhance mortality from systemic inflammation [104]. Similarly, although rTNF induces a septic shock state $[44,45,92]$, rTNF can also protect the host against lethal bacterial infection [161]. Finally, in a murine model for sepsis, protection from death can be achieved with a monoclonal antibody (mAb) preparation against LPS core (clone 20), without even influencing circulating TNF levels [162]. It is not clear whether this protection can be attributed to either the inhibition of LPS by this antibody preparation or to contaminating proteins such as protecting cytokines or desensitizing low dose endotoxin [163]. Nevertheless, the possibility to protect with the clone 20 preparation against mortality from sepsis notwithstanding an intact TNF response remains.

TNF is further considered to be involved in the pathophysiology of various non-bacterial infectious điseases, including AIDS and malaria. TNF, which is elevated during HIV infection [164], may enhance HIV expression [165]. This is in contrast to the antiviral activity of TNF which has been documented for various other vinuses [130, 131]. Intercurrent opportunistic infections often lead to progression of the disease, probably because they stimulate TNF production [166]. Wasting, cachexia and hypertrigliceridemia are common findings in AIDS [167]. These are considered to be due to the raised plasma TNF levels during HIV infection [168]. In malaria infection, notwithstanding its protective effects at low concentrations [106, 137], acute overproduction of TNF has been incriminated for the deleterious manifestations of cerebral malaria [169]. Chronic overproduction of TNF during malaria or other parasitic infections has been associated with the wasting syndrome which accompanies such diseases [170].

Acute overproduction of TNF has additionally been shown to be important for the pathogenesis of the systemic inflammatory response accompanying diverse non-infectious stimuli, including graft versus host disease [17!] and infusion with antithymocyte antibodies [172].

A local excess of TNF can potentially induce tissue damage and it has been proposed that TNF causes the tissue destruction, characteristic of a diversity of immuno-inflammatory diseases. TNF in synovial fluid from patients with meumatoid arthritis may be an important mediator of the disease [173] because it is capable of stimulating bone resorption [174] and inhibit proteoglycan deposition in cartilage [175]. There is also evidence that TNF is involved in tissue damage during multiple sclerosis [176], myocarditis [177] and diabetes mellitus [178]. 
Whereas acute exposure to TNF induces shock and tissue injury $[44,45,92]$, chronic presence of TNF induces cachexia [179, 180]. This is considered to underlie the cachectic state which accompanies chronic inflammatory and cancer disease $[40,42$, 138]. The final appearance of cachexia is shown to be the resultant of different effects from chronic presence of TNF in either the brain or in peripheral tissues [154]. This has been evidenced by experimental implantation of continuously TNF secreting tumors into different compartments of the body [154]. Chronic TNF release in the limb results in total body lipid and protein depletion, while TNF produced in the brain compartment causes the anorectic part of the cachectic response [154]. These experiments convincingly demonstrate the importance of the site of TNF production for the final biological effects.

\section{Conclusions}

At present, considerable evidence has been obtained that, rather than the invading microorganism, it is the excessive endogenous cytokine production which determines the seriousness of the alterations in physiology during infectious and non-infectious systemic inflemmatory disease. In contrast with hormones which are locally secreted by specialized gland cells, cytokines are produced by many different sorts of immune and nonimmune cells at many different sites of the body. The pleiotropic cytokines act as communication signals which at physiological concentrations coordinate metabolic and inflammatory responses during host defense to infection.

Cytokines are able to stimulate the release of other inflammatory mediators. Cytokine secretion is therefore liable to result in a complex cascade of excessive cytokine release. It appeared very difficult to sift out of this network the relative importance of the individual mediators. Apart from the quantitative differences in cytokine release, considerable quantitative and qualitative differences in cytokine effects can occur. Coexisting humoral mediators, the kinetics of cytokine release and the site of cytokine release all affect the final biological effect. These remarkable features of the cytokine system do not fit within the familiar framework which applies to the classical hormones. Our present knowledge of the rules which regulate the cytokine system appears to be insufficient to predict the net effect of cytokine production or cytokine inhibition during the complexity of septic disease.

It nevertheless becomes more and more clear that TNF takes a key position in the cytokine cascade. Not only through its direct effects, but rather through its indirect effects by triggering a cascade release of additional cytokines, TNF is able to induce many of the harmful events which occur during SIRS. Nevertheless, until nov, efforts to repress the cytokine cascade in SIRS patients with TNF-blocking agents only showed the incessant force of the cytokine systern. It is expected that a better understanding of the biological role of TNF and the rules which regulate its production and effect, makes it possible to develop future treatment strategies which effectively reverse the deleterious course of events during sepsis. 


\title{
DISCUSSION OF THE EXPERIMENTAL WORK
}

\begin{abstract}
Although TNF is generally considered to be central in the pathogenesis of shock and tissue injury during SIRS, uncertainties concerning the exact role of TNF in the mediation of the disease remain. In the light of the possible therapeutic effects of inhibition of TNF activity during SIRS, several physiological and pathophysiological aspects of TNF-involvement in the systemic inflammatory response have been studied in this thesis.
\end{abstract}

Une of the prootems' in the attempt to bemonstrate a putative cause-efrect retationstip between TNF plasma levels and septic shock was the fact that the presence of circulating TNF during disease has not uniformly been shown. This is considered to be partly due to the short half life of TNF in the circulation [92]. However, in spite of sampling blood for plasma TNF measurement shorly after outbreak of symptoms of sepsis, considerable discrepancies, have been reported in plasma TNF levels in these patients. For example, the plasma TNF levels of $10-100 \mathrm{pg} / \mathrm{ml}$ found in only $25 \%$ of septic patients tested [158] are in contrast with the plasma. TNF levels of $100-5000 \mathrm{pg} / \mathrm{ml}$ in $100 \%$ of patients with sepsis which were tested in another study [159]. In Studies 1 and 2 it has been evaluated whether different methods of plasma TNF measurement may have contributed to the different results in literature.

\section{Study 1}

The accuracy of the sandwich ELISA (enzyme-linked immuno sorbent assay) which has been developed in our laboratory for the measurement of human TNF has been estimated in Study 1. Interassay and intraassay coefficients of variance for the measurement of biologically active TNF in the concentration range between 0.5 and $5 \mathrm{ng} / \mathrm{ml}$ have been shown to be below $10 \%$. Sensitivity of the assay for detection of plasma TNF was 20 $\mathrm{pg} / \mathrm{ml}$. Biologically inactive, denatured human. TNF could not be detected by this sandwich TNF EL.ISA. It is therefore unlikely that, in biological fluids, the degradation products of TNF cause false positive results during the measurement of TNF levels with this ELISA. For Cynomolgous TNF, the biological activity has also been observed to correlate with the TNF concentration measured in the human TNF ELISA (data not given), which justifies the use of this sandwich ELISA for measurement of plasma TNF levels in septic Cynomolgous monkeys.

The data presented in Study 1 further demonstrate that the method of blood collection and processing is of major importance for the TNF levels measured. False positive results can be a consequence of induction of TNF release by LPS after blood sampling. 
LPS can be present in the circulation during endotoxernia or present in the collection tube as a consequence of pyrogen contamination of mainly the heparin prepared collection tubes. Gutteberg et al. showed that calcium chelators block in vitro production of TNF in whole blood [181]. In accordance, in Study $!$ it is shown that induction of false positive results is prevented when the collection systern contains EDTA. False negative data, on the other hand, have been observed to occur if separation of bloodcells from the plasma is delayed. This is presumably due to degradation of TNF after collection of blood. It has therefore been decided to routinely collect blood for plasma TNF measurement in EDTA tubes and separate bloodcells from plasma within 15 minutes after collection of blood.

\section{Study 2}

In Study 2, the influence of soluble TNF receptors on various TNF measurement methods has been studied. Soluble TNF receptors may be a source of discrepancy in detected amounts of circulating TNF during disease, because they bind and inhibit TNF [96]. Their plasma concentrations vary considerably as a consequence of the existence of steady interindividual differences [182] and because soluble TNF receptors are released into the circulation when TNF receptor bearing cells are activated as occurs during febrile disease $[97,99,100]$. Apart from either or not influencing TNF assays, such fluctuating levels of a protein with the potential to disturb the assaly may be a factor which additionally complicates plasma TNF measurement.

Antigen measurement with a competitive immunoassay is based on inhibition of binding between tracer antigen and antibody. Soluble TNF receptors are therefore expected to cause false positive results by scavenging tracer-TNF. Because biological fluids contain soluble TNF receptors, competitive immunoassays are unsuitable for the measurement of TNF in such fluids. This has been confirmed by the results of diverse investigators, who detected large amounts of plasma TNF using a competitive RIA (radio immuno assay) [159, 160], or a competitive ELISA [183]. Such plasma, however, lacked biological activity [183].

In study 2, the influence of soluble TNF receptors on TNF measurement has been evaluated in two different sandwich immunoassays which are non-competitive. It has been shown that soluble TNF receptors also affect the measurement results obtained with such non-competitive immunoassays. Because these assays do not depend on the binding of tracer TNF, the mechanism of interference must be different from the one described for competitive immunoassays. Given the intent to measure the concentration of biologically active TNF, it is required that soluble TNF receptors, which inhibit biological activity of TNF, accordingly prevent recovery of TNF in the immunoassay. It is however demonstrated in Study 2 that the extent of inhibition of the recovery of human rTNF in presence of soluble TNF receptors is different for the two immunoassays tested. Evidently, whereas the antibodies used in one sandwich immunoassay detect biologically active free TNF, the antibodies used in the other assay also recognize TNF/TNF receptor complexes. This finding has, besides the knowledge that competitive immunoassays 
should not be used for plasma TNF measurements, important implications with regard to the already published data on plasma TNF levels. Many reports which demonstrated increased amounts of plasma TNF in septic patients are based on immunoassays which give a positive signal on free TNF and on TNF/TNF receptor complexes or (for competitive assays) even on free soluble TNF receptors. If only positive TNF measurement results are taken into account which are obtained with TNF immunoassays whereof the results correlate with TNF bioassays, raised plasma TNF levels are not a constitutive finding in SIRS patients. But it should be noted that a lack of biologically active TNF in the circulation does not implicate that TNF is not involved in the pathogenesis of SIRS. For cachexia at least it has been demonstrated that continuous cerebral TNF levels are essential for induction of disease and not the presence of TNF in the systemic circulation [154]. A similar situation may apply to SIRS.

\section{Study 3}

Although diverse infectious and non-infectious causes for SIRS have been identified, the magnitude of the induced inflammatory reaction cannot be predicted by merely knowing the causative agent. General condition and genetic constitution are factors which additionally determine susceptibility to and seriousness of immuno-inflammatory diseases. Because TNF is supposed to be a central mediator of the inflammatory response, it has been proposed that differences in the ability to secrete TNF may underlie the divergence in clinical symptoms in response to comparable inflammatory causes. This supposition incited a search for the existence of variable TNF responses.

Evidence for a genetically based control of TNF synthesis has been obtained by the identification of different high and low TNF secretory genotypes [88], which correlate with stable differences in TNF secretion upon LPS-stimulation [87, 184]. Genetic control of TNF secretory capacity is considered to determine susceptibility to toxoplasmic encephalitis [185] and to MHC-linked auto-immune disease such as diabetes mellitus [88] or systemic lupus erythematosus [184].

Besides these stable constitutional differences, several variable factors have been demonstrated to affect peripherai blood monocyte cytokine responses. Functionally distinct monocyte subsets have been defined which differ in their TNF and PGE 2 secretory ability [186, 187]. In severe trauma or burn patients, who are at risk to develop septic shock, a shift in favor of high $\mathrm{PGE}_{2}$ and TNF producers has been demonstrated [186, 187].

There is also ample evidence that hemodialysis affects monocyte cytokine production [188]. This is considered to contribute to the systemic febrile and hemodynamic effects of hemodialysis and to the increased susceptibility to infection found in dialysis patients [189]. Until now, scientific effon focussed mainly on the involvement of the endogenous pyrogens TNF and IL-1 in the complications of hemodialysis. Influence of the uremic state and the dialysis procedure on both plasma cytokine levels and in vitro cellular cytokine production have been subject of investigation. It has previously been reported 
that plasma levels of TNF and IL-1 are increased in hemodialysis patients [188, 190192]. Furthermore, elevated cellular release of TNF and IL-1 in vitro has been observed in dialysis patients $[188,191,193,194]$. It has been confirmed that the activation of complement $[66,195]$ and the passage of microbial products from dialysate into the blood [196] induce synthesis of TNF and IL-1. However, close inspection of the published data reveals that the results are inconsistent. Some show that cytokine responsiveness is stimulated by the dialysis session and not because of an uremic state [188, 191]. In contrast, others demonstrate that monocytes are not primed for in vitro cytokine release by hemodialysis procedure, but rather by the uremic state [193, 194].

In Study 3, in order to further evaluate the different factors which may contribute to activation of peripheral blood leukocytes during hemodialysis, the influences of interaction between blood and dialysis membranes on plasma TNF, IL-6 and IL-8 levels and on cellular cytokine responsiveness have been monitored during in vivo and ex vivo hemodialysis. In these experiments, biocompatible dialysis membranes which prevent complement activation [197] were used. Bacterial contamination of dialysis fluid was less than 50 colony forming units $/ \mathrm{ml}$ and LPS content was less than $0.2 \mathrm{U} / \mathrm{ml}$. In contrast to previous reports, it was not possible to detect any TNF, IL-6 or IL-8 in patient's plasma during hernodialysis. The minimal pyrogen contamination of dialysis fluid and the use of biocompatible dialysis membranes may explain this lack of cytokine induction. However, the investigators which previously showed circulating TNF in hemodialysis patients used for TNF measurement either a competitive immunoassay [190], or an immunoassay which detects TNF/TNF receptor complexes [191, 192]. As demonstrated in Study 2, both these assays are unsuited for measurement of circulating free TNF. It may very well be that these investigators actually reported a rise in biologically inactive TNF, complexed with its receptor or of free soluble TNF receptors. The lack of biologically active cytokines in plasma during hemodialysis has been confimed by Powell et al. [198].

A second set of experiments presented in Study 3 evaluated in vitro cytokine responsiveness during hemodialysis. As stated above, earlier published results do not agree whether or not blood membrane interaction activates peripheral bloodcells to release cytokines. The results presented in Study 3 demonstrate that when bioconnpatible hemodialysis is performed, peripheral blood monocytes are not primed to enhance their cytokine responsiveness at the end of dialysis session. In contrast, in vitro TNF and IiL-6 release is even transitorily reduced at 30 minutes after start of hemodialysis. Because cytokine release is shown not to be reduced during ex vivo dialysis, the inhibited monocyte cytokine release during standard hemodialysis is not an immediate response to the interaction between the cells and the synthetic membrane. A likely explanation for this difference in effect is that during in vivo hemodialysis, a responsive monocyte subpopulation is preferentially entrapped into the microcirculation after membrane activation. Similar to the mechanism described for burn patients [185], the rapid reduction of TNF secretory ability during hemodialysis reflects a redistribution of the peripheral blood monocytes in favor of a non-responsive monocyte subpopulation. There 
is support for this concept in literature, because it has been reported that membraneactivated mononuclear cells which leave the venous side of the dialyzer do not return from the circulation to the arterial side of the dialyzer [199]. Finally, the existence of intraindividual fluctuations in TNF secretory ability, in addition to the stable genetically based interindividual variations, implicates that one single time point of measurement is not sufficient for assessment of individual's TNF responsive status.

\section{Study 4}

Another exogenous factor that affects in vitro cytokine release is the composition of dietary fat. Consumption of high amounts of the polyunsaturated $n-3$ fatty acids can inhibit [79] or enhance [80] in vitro IL-1 and TNF responsiveness. This influence seems to depend on animal species, cell type and duration of diet [80]. Consumption of fish oil, the main source of n-3 fatty acids, significantly decreases inflammatory events [77, $78]$ and reduces the incidence of cardiovascular disease $[78,200]$. It has been proposed that these beneficial biological effects of fish oil are mediated by its influence on cytokine production $[79,80]$. It is disputed whether the inhibition of the lipoxygenase pathway during fish oil consumption is involved in affecting cytokine responsive capacity [201].

The general view is that dietary fat influences cardiovascular risk profile and immune response if it contains adequate amounts of polyunsaturated fatty acids. Palm oill is a dietary fat which, although it contains approximately $50 \%$ saturated fatty acids [202], does not behave like a saturated fat. Dietary intake of palm oil unexpectedly has beneficial effects on serum lipid profile [203] and has antithrombotic effects [204]. Notwithstanding these effects on cardiovascular disease determinants, the influence of palm oil consumption on the inflammatory response is still largely unknown. In Study 4, the influence has been measured of dietary palm oil on the in vitro LPS-induced release of TNF, and also of IL- 6 and IL- 8 by peripheral blood leukocytes. Dietary palm oil consumption did not affect maximal in vitro cytokine release. Neither was the tendency to produce IL-6 and IL-8 in vitro influenced by this dietary protocol. For induction of maximal peripheral blood monocyte TNF secretion, however, a stronger LPS stimulus seemed io be necessary during replacement of dietary fat by palm oil.

It can be speculated that vitamin $\mathbf{E}$ is important for the influence of palm oil consumption on monocyte TNF secretion. Palm oil contains high amounts of the vitamin $\mathrm{E}$ isomers tocopherols and tocotrienols [205] and it can be expected that vitamin E reduces. LPS-induced TNF release. Vitamin E, being a lipid soluble antioxidant, scavenges reactive oxygen species and reduces lipoxygenase activity [206]. Both of these mediators enhance TNF production $[72,82]$. It has been shown that dietary vitamin $\mathrm{E}$ supplementation prevents exercise-enhanced release of IL-1 [207]. But it needs further investigation to confirm whether vitamin $\mathrm{E}$ actually affects TNF production. Support for the biological importance of the vitamin $\mathrm{E}$ constituent of palm oil has been obtained by the demonstration that consumption of a vitamin $\mathrm{E}$ concentrate from palm oil induces similar effects on serum. lipid profile as consumption of the complete palm oil product 
[208]. The clinical relevance of the observed biological effects of palm oil consumption, however, remains to be elucidated.

\section{Study 5}

in addition to TNF, various other humoral inflammatory mediators, including $\mathrm{IL}-6$ and $\mathrm{PAF}$, have been implicated in the pathophysiological consequences of severe infection. Administration of IL-6 or PAF induces some of the characteristic derangements associated with septic shock. PAF induces hypotension, increased vascular permeability and death [209-21!]. IL-6 induces fever [212] and acule phase protein synthesis [213]. PAF and $\mathrm{L}-6$ are released into the circulation during endotoxemia $[214,215]$ and both PAF antagonists and anti-IL-6 antibodies protect against LPS-induced pathology $[2 \mathbf{i} 1,215$, 216]. In view of the important roles of TNF, IL-6 and PAF during severe systemic inflammation, the interrelationship of these mediators has been investigated in Study 5 . in vitro LPS-elicited cytokine release by murine macrophages has been compared with cytokine production during in vivo LPS-induced murine shock. Time course measurements demonstrated that LPS-challenge induces in mice a rapid release of TNF, reaching a maximum at 1 hour. This is before the peak release of IL-6 which occurs at 2 hours. Pretreatment of LPS-exposed mice with anti-TNF antibodies reduced the IL-6 response for $50 \%$. Both results show that TNF is a stimulus for IL-6 release during endotoxemia. This is in agreement with earlier reported observations that TNF stimulates IL-6 production in vitro in cell cultures $[217,218]$ and, in vivo, after intravenous adiministration or RTNF to man [219]. In the experiments presented in Study 5, anti-TNF did not prevent the complete IL 6 response. This indicates that other stimuli than TNF may additionally be involved in LPS-induced IL-6 release. LPS and IL-1, which are potent inducers of IL-6, release $[2.12,217,218]$, can be such stimuli. But because TNF is an intermediate in LPS-induced IL-1 synthesis [107-109], the reduced IL-6 response in this model can be a consequence of a reduced $\mathrm{L}-\mathrm{l}$ response after administration of anti-TNF antibodies. It is therefore improbable that $\mathrm{IL}-1$ was a strong stimulus for the remaining IL-6 response during anti-TNF treatment.

The in vitro experiments presented in Study 5 show that PAF is involved in LPSinduced TNF release, since PAF antagonists reduce macrophage TNF response. In accordance, PAF has been reported to induce the production of TNF in vitro [220] and to be released prior to TNF during in vivo endotoxemia [214]. The in vivo experiments. presented in Study 5, however, demonstrate that PAF antagonists do not influence LPSinduced TNF secretion. This indicates that, in vivo. PAF is not essential for LPS-induced TNF secretion. In spite of this lack of effect on in vivo TNF response, PAF antagonists. have repeatedly been shown to prevent LPS-induced shock and tissue injury [2.11, 215]. Similarly, protective effects against LPS have been documented from anti-IL-6 antibody treatment, without a reduction of serum TNF [216]. These observations illustrate that it is not TNF which is the ultimate cause SIRS, but that it is the complete cytokine cascade which provokes pathology during sepsis. 


\section{Study 6}

During septic shock, neutrophils infiltrate early into the lungs and other vital organs [222]. The importance of neutrophils for inducing tissue injury and vascular leakage which accompanies septic shock has been demonstrated in laboratory studies with neutrophil depleted animals [221]. In vitro studies have shown that both activated immune cells and activated endothelial cells contribute to the recruitment of different leukocyte populations to the site of inflammation [reviewed in 126]. On the basis of such in vitro observations, it can be proposed that the expression of adhesion molecules for leukocytes on endothelial cells is an important event in the process which leads to tissue damage during SIRS. However, in vivo data which support this hypothesis are limited. In Studies 6 and 7, immunohistochemical techniques were used to study the in vivo vascular expression of the endothelial cell adhesion molecule E-selectin/ELAM-1 during SIRS.

E-selectin is the recent nomenclature for ELAM-1 [223], a membrane antigen expressed only on endothelial cells $[224,225]$. E-selectin has been shown in vitro to be important for adhesion of neutrophils [226]. Endothelial cells do not basally express E-selectin, but after exposure to TNF, IL-1 or LPS, surface expression is induced within 2 hours [224. 225]. E-selectin expression in vitro is maximal at 4-6 hours and then rapidly declines [224, 225]. IFN-gamma prolongs expression of E-selectin in vitro, which may be important during in vivo inflammation [110]. It has been demonstrated that in vivo $\mathrm{E}$ selectin expression can be readily induced by intradermal administration of LPS [227]. TNF, IL-1 [228] or agents that cause delayed type hypersensitivity reactions [228, 229]. In these experimentally elicited acute inflammatory reactions, E-selectin expression correlates with neutrophil adhesion. In human tissue specimens which were obtained from the site of an active inflammatory reaction, local E-selectin expression has been demonstrated on the postcapillary venules [229].

In Study 6, with immune histological methods, tissue E-selectin expression has been examined afier experimental elicitation of SIRS by intravenous infusion of LPS into Cynomolgous monkeys. The results presented demonstrate that during such a generalized inflammatory state, as evidenced by systemic release of TNF and IL-6, E-selectin expression is induced on vascular endothelium of almost every organ. Expression is most pronounced in skin and lung tissue. In contrast with in vivo E-selectin expression in inflamed lymph nodes or locally inflamed skin, E-selectin expression during systemic inflammation is a generalized phenomenon and the antigen can also be demonstrated on endothelium lining the arteries and larger veins. The pronounced expression of E-selectin on the endothelium of the lung during SIRS is considered to represent the acute inflammation which is involved in ARDS.

\section{Study 7}

In Study 7, tissue E-selectin expression has been investigated in skin biopsies taken from patients with SIRS following severe peritonitis. Although the primary site of inflammation was the peritoneum, de novo expression of E-selectin could be demonstrated on 
vessels of the skin when biopsies were taken within 12 hours after start of symptoms. The inflamed peritoneum apparently induces expression of E-selectin on remote endothelial cells, presumably by the systemic release of specific activating agents. The presence of LPS or TNF could be demonstrated in plasma from 3 out of 5 patients with positive skin biopsies for E-selectin. These factors may have been such distance-activators.

Various additional examples of in vivo E-selectin expression demonstrate the involvement of TNF in inducing E-selectin during SIRS. E-selectin expression has also been measured in skin biopsies taken from patients infused with OKT3. OKT3 is a sterile immunosuppressive monoclonal antibody preparation which is directed against T-cells. Infusion of antilymphocyte antibodies induces serious systemic side effects, concurrent with a peak release of TVF, but not of $\mathrm{L}-1$, into the circulation [172]. De novo Eselectin expression has been observed in skin biopsies taken more than 3 hours after start of OKT3 infusion (unpublished results). It has further been reported that tissue Eselectin expression during bacteremic shock is much more pronounced than during hypovolemic shock in baboons [230] which correlates with the higher levels of circulating cylokines and LPS during bacteremia. The selective importance of TNF in E-selectin induction during bacteremia appears from the fact that anti-TNF treatment diminishes E-selectin expression in these septic monkeys despite high levels of circulating LPS [231]. These data together demonstrate the involvement of TNF in the systemic vascular expression of E-selectin in SIRS patients.

In spite of being an adhesion molecule for neutrophils, the functionai role of E-selectin in the induction of neutrophil-induced vascular damage in the process of tissue injury is not clear until now. Demonstration of in vivo biological effects from E-selectin inhibiting antibodies is difficult, because only an anti-E-selectin $F(a b)$ preparation is appropriate to inhibit the function of the adhesion molecule. Timing of administration of $\mathrm{F}(\mathrm{ab})$ proteins probably is critical, because $\mathrm{F}(\mathrm{ab}) \mathrm{s}$ are rapidly cleared. Intact $\mathrm{Ig}$, however, would enhance neutrophil adhesion by a mechanism which involves Fc-gamma receptors on neutrophils [226]. It has nevertheless been demonstrated that anti-E-selectin mAb prevents both neutrophil infiltration and inflammatory symptoms in a primate model of acute airway inflammation [232] and reduces vascular injury in immune complex alveolitis in the rat lung [233]. Broncho-alveolar lavage fluid from such rats contains high levels of TNF whereas animals pretreated with anti-TNF were protected from lung injury [234]. These experiments therefore provide evidence for a functional role of E-selectin in the induction of inflammatory lung damage and for the involvement of TNF in this process. This implicates that prevention of systemic E-selectin expression by TNF-blocking agents may be a mechanism of protection against tissue injury during SIRS.

\section{Study 8}

Although prophylactical interference with the endogenous TNF response effectively prevents lethality and tissue injury from experimental sepsis, treatment with anti-TNF antibodies coinciding with or posterior to experimental induction of disease has been 
disappointing [48, 49]. Because the interval between the start of SIRS and admission to the ICU can vary considerably between patients, the utility of anti-TNF treatment of SIRS patients may be limited. It must however be noted that most of the studies which tested the efficacy of anti-TNF antibodies have been performed in animals with septic shock induced by bolus injections or continuous infusions of large amounts of LPS or bacteria, which causes a short peak release of TNF $[49,91]$. The clinical syndrome of SIRS is much more complex with recurrent episodes of endotoxemia. Repetitive exposure to LPS is known to alter the LPS-induced TNF response, causing either tolerance or enhanced sensitivity for L.PS, which depends on dose and time schedules [73]. Therefore, the TNF release pattern during SIRS is expected to be dissimilar to the short peak release which occurs after experimental induction of shock by administration of a single high dose of LPS or bacteria. Accordingly, a sustained rise in serum TNF has been demonstrated during sublethal murine peritonitis after treatment with antibiotics [235]. This implicates that reversibility of TNF effect should be studied in models with. sustained presence of TNF. In Study 8, the relation between the duration of TNF receptor triggering and the biological effect has been studied in two in vitro models.

The results presented in Study 8 demonstrate that TNF has to be continuously present for more than 16 hours to fully exert its cytocidal effect on L929 cells which is a TNF sensitive murine fibrosarcoma cell line. The effect of a LD100 dose of TNF can be abolished completely by addition of anti-TNF after 4 hours of incubation with TNF, notwithstanding the fact that TNF reaches equilibrium with its receptor within 1 hour [236] and that this is followed by very rapid post receptor events [237, 238]. It may be that it is necessary to trigger the TNF receptor for hours in order to reach the maximal cytotoxic effect because the mechanism of cell killing involves the formation of reactive oxygen species in the mitochondria [239]. This is not an on/off phenomenon, but rather requires a prolonged high concentration of oxygen radicals.

Apart from inducing the lysis of tumor cells, which does not involve gene activation [240]. TNF elicits a variety of cellular processes which are mediated by protein synthesis and require an intact nucleus function [241]. This implicates that different postreceptor mechanisms are involved in the wide range of TNF actions. Accordingly, it has never been possible to demonstrate a correlation between cytotoxicity and other responses to TNF. In mice it has even been shown that during induction of tolerance for TNF, the cytocidal effects of TNF can be separated from other cellular responses. This can result in a very effective anti-tumor TNF activity with minor systemic toxicity [242], The necessity of a prolonged exposure to TNF for a maximal cytotoxic effect may therefore not apply to its systemic toxic effects during SIRS. In the second set of experiments presented in Study 8, it is demonstrated that also for TNF-induced Eselectin expression on human endothelial cells, the TNF receptor has to be continuously occupied with TNF in order to reach and maintain maximal antigen expression. The corresponding results obtained for the two different TNF effects indicate that a common mechanism of receptor activation may be responsible for the requirement of a prolonged TNF receptor trigger duration. Electron microscopic studies showed that after TNF binds 
to its receptor, the TNF/TNF receptor complexes are internalized and are degraded in the lysosomes [243]. Simultaneousily, TNF receptors are continuously translocated to the cell surface [244]. These observations are compatible with a signalling process for TNF with a very short duration, which has to be repeated continuously to reach a maximal signal. This may be an endogenous control mechanism to protect the host against the effects of a brief overshoot of TNF. This may additionaliy be an important feature which allows therapeutic intervention in the harmful effects of a sustained excessive release of TNF during SIRS. 
Cod achiep de wereld in zes dogen.

Hij kon dit want Hij hoefde niet te communiceren.

(W. Engelberts)

\section{REFERENCES CHAPTERS 1 AND 2}

1. Aronson MD \& Bor DH. Blood cultures. Ann.Int.Med. 1987 106:246-253.

2. Bone RC, Balk RA, Cerra FB, Dellinger RP, Fein AM, Knaus WA, Schein RMH \& Sibbald WJ. Definitions for sepsis and organ failure. Guidelines for the use of innovative therapies in sepsis. Chest. 1992 101:1644-1655.

3. Skillman JJ, Bushnell LS, Goldman H \& Silen W. Respiratory failure, hypotension, sepsis, and jaundice: a clinical syndrome associated with lethal hemorrhage from acute stress ulceration of the stomach. AmJ.Surg. 1969 117:523-530.

4. Eiseman B, Beart R \& Norton L. Multiple organ failure. Surg.Gyn.Obstet. 1977 144:323-326.

5. Goris RJA, te Boekhorst TPA, Nuytinck JKS \& Gimbrere JSF, Multiple organ failure: generalized autodestructive inflammation? Arch.Surg. 1985 120:1109-1115.

6. Goris RJA, Boekholtz WKF, van Bebber IPT, Nuytinck JKS \& Schillings PHM. Multiple organ failure and sepsis without bacteria. An experimental model. Arch.Surg. 1986 121:897-901.

7. McGowan Jr. JE, Bames MW \& Finland M. Bacteremia at Boston City Hospital: Occurrence and mortality during 12 selected years (1935-1972), with special reference to hospital-acquired cases. JInfect.Dis. 1975 132:316-335.

8. Weinstein MP, Reller LB, Murphy JR \& Lichtenstein KA. The clinical significance of positive blood cultures: a comprehensive analysis of 500 episodes of bacteremia and fungemia in adults. I. Laboratory and epidemiologic observations. Rev.Infect.Dis. 1983 5:35-53.

9. Geerdes HF, Ziegler D, Lode H, Hund M, Loehr A, Fangmann W \& Wagner J. Septicemia in 980 patients all a University hospital in Berlin: prospective studies during 4 selected years between 1979 and 1989. Clin.Infect.Dis. 1992 15:991-1002.

10. Kreger BE, Craven DE \& McCabe WR. Gram-negative bacteremin III. Reassessment of etiology, epidemiology and ecology in 612 patients. Am.J.Med. 1980 63:332-343.

11. EPIC study, Bruining HA. (personal communication).

12. Sitges-Serra A, Puig P, Juarrietta E, Garau J, Alastrue A, Sitges Creus A. Catheter sepsis due to staphylococcus epidermidis during parenteral nutrition. Surg.Gyn.Obstet. 1980 151:481-483.

13. Bone RC, Fisher CJ, Clemmer TP, Slotman GJ, Metz CA, Balk RA, The Methylprednisolone Severe Sepsis Study Group. Sepsis syndrome: A valid clinical entity. Crit.Care.Med. 1989 17: 389-393.

14. Kreger BE, Craven. DE \& McCabe Wh. Gram-negative bacteremia IV. Re-evaluation of clinical features and treatment in $6 \| 2$ patients. Am_IMed. 1980 63:344-355.

15. Wiles JB, Cerra FB, Siegel JH \& Border JR. The systemic septic response: does the microorganism matter? Crit.Care.Med. 1980 8:55-60.

16. Cullen DJ, Ferrarn LC, Briggs BA, Walker PF \& Gilbent JG. Survival, hospitalization charges and follow-up results in critically ill patients. N.EnglJ.Med. 1976 294:982-987.

17. Knaus WA. Wagner DP, Draper EA, Zimmerman JE, Bergner M, Bastos PG, Sirio CA, Murphy DJ, Lotring T, Damiano A \& Harrell Jr FE. The APACHE III prognostic system. Risk prediction of hospital mortality for critically ill hospitalized adults. Chest. 1991 100:1619-1636. 
18. Parillo JE, Burch C, Shelhamer JH, Parker MM, Natanson C \& Schuette W. A circulating myocardial depressant substance in humans with sepstic shock. Septic shock patients with a reduced ejection fraction have a circulating factor that depresses in vitro myocardial cell performance. J.Clin.Invest. 1985 76:1539-1553.

19. Franke FE. Action of toxic doses of the polysaccharide from Serratia marcescens (Bacillus prodigiosus) in the dog and guinea pig. J.Natl.Cancer.Inst. 1944 5:185-203.

20. Shenep IL \& Mogan KA. Kinetics of endotoxin release during antibiotic therapy for experimental gram-negative bacterial sepsis. J.Infect.Dis. 1984 150:380-388.

21. Morrison DC \& Kline LF. Activation of the classical and properdin pathways of complement by bacterial lipopolysaccharides (L.PS). J.Immunol. 1977 118:362-368.

22. Kaiter ES, van Dijk WC, Timmerman A. Verhoef J \& Bouma BN. Activation of purified human plasma prekallikrein triggered by cell wall fractions of Escherichia coli and Staphylococcus aureus. J.Infecr.Dis. 1983 148:682-691.

23. Fearon DT, Ruddy S, Schur PH \& McCabe WR. Activation of the properdin pathway of complement in patients with gram-negative bacteremia. N.Engl.J.Med. 1975 292:937. 940.

24. Hack CE, Nưijens JH, Felt-Bersma RJF, Schreuder WO, Eerenberg-Belmer AJM, Paardekooper J, Bronsveld W \& Thijs LG. Elevated plasma levels of the anaphylatoxins $\mathrm{C} 3 \mathrm{a}$ and $\mathrm{C} 4 \mathrm{a}$ are associated with a fatal-outcome in sepsis. Am.J.Med. 1989 86:20-26.

25. Schirmer JW, Schimer JM, Naff GE \& Fry DE. Systemic complement activation produces hemodynamic changes characteristic of sepsis. Arch.Surg. 1988 123:316-321.

26. Sacks T, Moldow CF, Craddock PR, Bowers TK \& Jacob HS. Oxygen radicals mediate endothelial cell danage by complement-stimulated granulocytes. J.Clin.Invest. 1978 61:1161-1167.

27. Jacobs HS. The role of activated complement and granulocytes in shock states and myocardial infarction. J.Lab.Chin.Med. 1981 98:645-653.

28. Fletcher JR., Ramwell PW \& Herman CM. Prostaglandins and the hemodynamic course of endotoxin shock. J.Surg.Res. 1976 20:589-594.

29. Fink MP, Rothschild HR, Deniz YF \& Cohn SM. Complement depletion with Naje haje cobra venom factor limits prostaglandin release and improves visceral perfusion in porcine endotoxic shock. J.Trauma. 1989 29:1076-1084.

30. Terashita ZI, Imura Y, Nishikawa K \& Sumida S. Is platelet activating factor (PAF) a mediator of endotoxin shock? Eur.J.Pharmacol. 1985 109:257-261.

31. Malech HL \&: Gallin JI. Neutrophils in human disease. N.Engl.J.Med. 1987 317:687-694.

32. Brandtzaeg P. Kierulf P, Gaustad P, Skulberg A, Bruun JN, Halvorsen S \& Sorensen E. Plasma endotoxin is a predictor of multiple organ failure and death in systernic meningococcal disease. J.hnfect.Dis. 1989 159:195-204.

33. Guillou PJ. Biological variation in the development of sepsis after surgery or trauma Lancer. 1993 342:217-220.

34. Todd J \& Fishaut M. Toxic-shock syndrorne associated with phage-group-I staphylicxocci. Lancet. 1978 ii: $1116-1118$.

35. Watson J. Kelly K, Largen M \& Taylor BA. The genetic mapping of a defective LPS responsive gen in $\mathrm{C} 3 \mathrm{H} / \mathrm{HeJ}$ mice. J.mmunol, 1978 120:422-424.

36. Michalek SM, Moore RN, McGhee JR, Rosensteich DL \& Mergenhagen SE. The primary role of lymphoreticular cells in the mediation of host responses to bacterial endotoxin. J.Infect.Dis. 1980 141:55-63.

37. Carswell EA, Old LJ, Green S, Fiore N \& Williamson B. An endotoxin-induced serum factor that causes necrosis of tumors. Proc_Natl_Acad.Sci.USA. 1975 72:3666-3670. 
38. Aggarwal BB, Kohr WJ, Hass PE, Moffat B, Spencer SA, Henzel WJ, Bringman TS, Nedwin GE, Goeddel DV \& Harkins RN. Human tumor necrosis factor. Production purification, and characterization. J.Biol.Chem. 1985 260:2345-2354.

39. Pennica D, Nedwin GE, Hayflick JS, Seeburg PH, Derynck R, Palladino MA, Kohr WJ. Aggarwal BB \& Goeddel DV. Human tumour necrosis factor: Precursor structure, expression and homology to lymphotoxin. Nature. 1984 312:724-729.

40. Beutler B, Greenwald D, Hulmes JN, Chang M, Phan YCE, Mathison J, Ulevitch R \& Cerami A. Identity of tumor necrosis factor and the macrophage-secreted cachectin. Nature. 1985 316:552-554.

41. Beutler B, Mahoney J, Le Trang N, Pekala P \& Cerami A. Purification of cachectin, a lipoprotein lipase-suppressing hormone secreted by endotoxin-induced RAW 264.7 cells. JExp.Med. 1985 161:984-995.

42. Cerami A, Ikeda Y, Le Trang N, Hotez PJ \& Beutler B. Weight loss associated with an endotoxin-induced mediator from peritoneal macrophages: the role of cachectin (tumor necrosis factor). Immunol Lett. 1985 11:173-177,

43. Chapman PB, Lester TJ, Casper ES, Gabrilove J,, Wong GY, Kempin SJ, Gold PJ. Welt S, Warren RS, Starnes HF, Sherwin SA, Old LJ \& Oettgen HF, Clinical pharmacology of recombinant human tumor necrosis factor in patients with advanced cancer. J.Clin.Oncol. 1987 5:1942-1951.

44. Tracey KJ, Beutler B, Lowry SF, Merryweather J, Wolpe S, Milsark IW, Hariri RJ, Fahey III TJ, Zentella A, Albert JD, Shires GT \& Cerami A. Shock and tissue injury induced by recombinant cachectin. Science. 1986 234:470-474.

45. Tracey KJ, Lowry SF, Fahey III TJ, Albert JD, Fong Y, Hesse D, Beutler B, Manogue KR, Calvano S, Wei H, Cerami A \& Shires GT. Cachectin/tumor necrosis factor induces lethal shock and stress hormone responses in the dog. Surg.Gynecol.Obstet. 1987 164:415-422.

46. Creech Jr. O, Krementz ET, Ryan RF \& Winblad JN. Chemotherapy of cancer: Regional perfusion utilizing an extracorporeal circuit. Ann.Surg. 1958 148:616-632.

47. Lienard D, Ewalenko P, Delmotte JJ, Renard N \& Lejeune FJ. High-dose recombinant tumor necrosis factor alpha in combination with interferon gamma and melphalan in isolation perfusion of the limbs for melanoma and sarcoma. J.Clin.Oncol, 1992 10:52-60.

48. Beutler B, Milsark IW \& Cerami A. Passive immunization against cachectin/tumor necrosis factor protects mice from lethal effect of endotoxin. Science. 1985 229:869-871.

49. Tracey KJ, Fong Y, Hesse DG, Manogue KR, Lee AT, Kho GC, Lowry SF \& Cerami A. Anti-cachectin/TNF monoclonal antibodies prevent septic shock during lethal bacteremia. Nature. 1987 330:662-664.

50. Beutler B, Krochin N, Milsark IW, Luedke C \& Cerami A. Control of cachectin (tumor necrosis factor) synthesis: mechanism of endotoxin resistance. Science. 1986 232:977. 980.

51. Cohen S, Bigazzi PE \& Yoshida T. Similarities of T cell function in cell-mediated immunity and antibody production. Cell.Immunol. 1974 12:150-159.

52. Aarden LA,Brunner TK, Cerottini J-C, Dayer J-M, de Weck AL, Dinarello CA, Di Sabato G, Farrar J, Gery I, Gillis S, Handschumacher RE, Henney CS, Hoffman MK, Koopman WJ, Krane SM, Lachman LB, Lefkowits I, Mishell RI, Mizel SB, Oppenheim J, Paetkau V, Plate J, Rollinghoff M, Rosenstreich D, Rosenthal AS, Rosenwasser L. Schimpl A, Shin HS, Simon PL, Smith KA, Wagner H, Watson JD, Wecker E \&. Wood DD. Revised nomenclature for antigen-nonspecific T-cell proliferation and helper factors. J.Jmmunol. 1979 123:2928-2929. 
53. Vilcek J \& Le J. Immunology of cytokines: an introduction. from The Cytokine Handbook. 1991 Acad.Piess.limited. 1-17.

54. Spom MB \& Roberts AB. Peptide growth hormones are multifunctional. Nafure. 1988 332:217-220.

55. Matthews N. Tumor necrosis factor from the rabbit II. Production by monocytes. BrJ Cancer. 1978 38:310-315.

56. Mannel DN, Moore RN \& Mergenhagen SE. Macrophages, as a source of tumoricidal activity (tumor necrosis factor). Infect.Immun. 1980 30:523-530.

57. Cuturi MC, Murphy M, Costa-Giomi MP, Weinman R, Perussia B \& Trinchieri G. Independent regulation of tumor necrosis factor and lymphotoxin production by human peripheral bloodl lymphocytes. J.Exp.Med. 1987 165:1581-1594.

58. Wrigh SC \& Bonavida B. Studies, on the mechanism of natural killer cell-mediated cytotoxicity. VIl. Functional comparison of human natural killer cytotoxic factors with recombinant lymphotoxin and tumor necrosis factor. J.Immunol. 1987 138:1791-1798.

59. Djeu JY, Serbousek D \& Blanchard DK. Release of tumor necrosis factor by human polymorphonuclear leukocytes. Blood. 1990 76:1405-1409.

60. Ferrante A, Staugas R.E, Rowan-Kelly B, Bresatz S, Kumaratilake LM, Rzepczyk CM \& Adolf GR. Production of tumor necrosis factors alpha and beta by human mononuclear leukocytes stimulated with mitogens, bacteria, and malarial parasites. Infect.Immun. 1990 58:3996-4003.

61. Djeu JY, Blanchard DK, Richards AL \& Friedman H. Tumor necrosis factor induction by Candida albicans from human natural killer cells and monocytes. $j$ J.mmunol. 1988 141:4047-4052.

62. Hampton RY, Golenbock DT \& Raetz CRH. Lipid A binding sites in membranes of macrophage tumor cells. J.Biol.Chem. 1988 263:14802-14807.

63. Lei MG \& Morrison DC. Specific endotoxic lipopolysaccharide-binding proteins on murine splenocytes. 1. Detection of lipopolysaccharide binding sites on splenocytes and splenocyte subpopulation. J.Immunol. 1988 141:996-1005.

64. Wright SD, Ramos RA, Tobias PS, Ulevitch RJ \& Mathison JC. CD 14, a receptor for complexes of lipopolysaccharide (LPS) and LPS binding protein. Science. 1990 249:1431-1433.

65. Schumann RR, Leong SR, Flaggs GW, Gray PW, Wright SW, Mathison JC, Tobias PS \& Ulevitch RJ. Sinucture and function of lipopolysaccharide binding protein. Science. 1990 249:!429-! 43.I.

66. Okusawa S. Yancey KB. vani der Meer JWM. Endres S. Lonnemann G. Hefter K, Frank MM, Burke JF Dinarello CA, Gelfand JA. C5a stimulates secretion of tumor necrosis facior fron human mononuclear cells in vitro. J.Exp.Med. 1988 168:443-448.

67. Eierman DF, Johnson CE \& Haskill JS. Human monocyte inflammatory mediator gene expression is selectively regulated by adherence substrates. J.Immuno!. 1989 142:19701976.

68. Debets JMH, van der Linden CJ. Dieteren IEM, Leeuwenberg JFM \& Buurman WA. Fc-receptor çross-linking induces rapid secretion of tumor necrosis factor (cachectin) by human peripheral blood monocytes. J.Immunol. 1988 141:1197-1201.

69. Hallahan DE, Spriggs DR. Becket MA, Kufe DW \& Weichselbaum RR. Increased tumor necrosis factor $\alpha$ mRNA after cellular exposure to ionizing radiation. Proc_Natl_Acad.Sci.USA. 1989 86:10104-10107. 
70. Philip R \& Epstein L.B. Tumour necrosis factor as immunomodulator and mediator of monocyte cytotoxicity induced by itself, gamma-interferon and interleukin-1. Nature. 1986 323:86-89.

71. Debets JMH, van der Linden CJ, Sproncken IEM \& Buurman WA. T cell-mediated production of tumour necrosis factor $\alpha$ by monocytes. Scand J.Immunol. 1988 27:601. 608.

72. Chaudhri G. Clark LA. Reactive oxygen species facilitate the in vitro and in vivo lipopolysaccharide-induced release of tumor necrosis factor. J.Immunol. 1989 143:12901294.

73. Mathison JC, Virca GD, Wolfson E, Tobias PS, Glaser K \& Ulevitch RJ. Adaptation to bacterial lipopolysaccharide controls lipopolysaccharide-induced tumor necrosis factor production in rabbit macrophages. J.Clin.Invest. 1990 85:1108-1118.

74. Han J, Thompson P \& Beutler B. Dexamethasone and pentoxifylline inhibit endotoxin-induced cachectin/tumor necrosis factor synthesis at separate points in the signaling pathway. J.Exp.Med. 1990 172:391-394.

75. Schade UF. Pentoxifylline increases survival in murine endotoxin shock and decreases formation of tumor necrosis factor. Circ.Shock. 1990 31:171-181.

76. Ferguson Chanowitz KM, Katoes Jr. AS, Pickett WC, Kaplan JB, Sass PM, Oronsky AL. \& Kerwar SS. Platelet-activating factor or a platelet-activating factor antagonist decreases tumor necrosis factor-alpha in the plasma of mice treated with endotoxin. J.Infect.Dis. 1990 162:1081-1086.

77. Kremer JM, Jubiz W, Michalek A, Rynes RI, Bartholomew LE, Bigaouette J, Timschalk M. Beeler D \& Lininger L. Fishoil fatty acid supplementation in active rheumatoid arthritis: a double-blinded, controlled, crossover study. Ann.Int.Med. 1987 106:497-503.

78. Kromann N \& Green A. Epidemiological studies in the Upernavik district, Greenland: incidence of some chronic diseases 1950-1974. Acta.Med.Scand. 1980 208:401-406.

79. Endres S, Ghorbani R, Kelley VE, Georgilis K, Lonnemen G, van der Meer JWM, Cannon JG, Rogers TS, Klempner MS, Weber PC, Schaeffer EJ, Wolff SM \& Dinarello CA. The effect of dietary supplementation with n-3 polyunsaturated fatty acids on the synthesis of interleukin-1 and tumor necrosis factor by mononuclear cells. N.Engl J.Med. 1989 320: 265-271.

80. Blok WL, Vogels MTE, Curfs JHAJ, Eling WMC, Buurman WA \& van der Meer JWM. Dietary fish-oil supplementation in experimental gram-negative infection and in cerebral malaria in mice. J.Infect.Dis. 1992 165:898-903.

81. Kunkel SL, Spengler M, May MA, Spengler R, Larrick JW \& Remick D. Prostaglandin $\mathrm{E}_{2}$ regulates macrophage-derived tumor necrosis factor gene expression. J.Biol.Chem. 1988 263:5380-5384.

82. Horiguchi J, Spriggs D, Imamura K, Stone R, Luebbers R \& Kufe D. Role of arachidonic acid metabolism in transcriptional induction of tumor necrosis factor gene expression by phorbol ester. Mol.Cell.Biol. 1989 9:252-258.

83. Bachwich PR, Chensue SW, Larrick JW \& Kunkel SL. Tumor necrosis factor stimulates interleukin-1 and prostaglandin $\mathrm{E}_{2}$ production in resting macrophages. Biochem.Biophys. Res.Commun. 1986 136:94-101.

84. Endo H, Akahoshi T \& Kashiwazaki S. Additive effects of IL-I and TNF on induction of prostacyclin synthesis in human vascular endothelial cells. Biochem.Biophys.Res. Commun. 1988 156:1007-1014. 
85. Okusawa S, Gelfand JA, Ikejima T, Connolly RJ \& Dinarello CA. Interleukin 1 induces a shock-like state in rabbits. Synergism with tumor necrosis factor and the effect of cyclooxygenase inhibition. J.Clin.Jnvest. 1988 81:1162-1172.

86. Kettelhut IC, Fiers W \& Goldberg, AL. The toxic effects of tumor necrosis factor in vivo and their prevention by cyclooxygenase inhibitors. Proc.Natl_Acad.Sci.USA. 1987 84:4273- 4277 .

87. Molvig J, Baek L, Christensen P. Manogue KR, Vlassara H, Platz P, Nielsen LS, Svejgaard A \& Nerup J. Endotoxin-stimulated human monocyte secretion of interleukin 1 , tumour necrosis factor alpha, and prostaglandin E2 shows stable interindividual differences. Scand_I.Immunol. 1988 27:705-716.

88. Pociot F, Briant L, Jongeneell CV, Mölvig J, Worsaae H, Abbal M. Thomsen M, Nerup J \& Cambon-Thomsen A. Association of tumor necrosis factor (TNF) and class II major histocompatibility complex alleles with the secretion of TNF- $\alpha$ and TNF- $\beta$ by human mononuclear cells: a possible link to insulin-dependent diabetes mellitus. Eur_J.Immunol. 1993 23:224-231.

89. Zuckerman SH, Shellhaas J \& Butler L.D. Differential regulation of lipopolysaccharide-induced interleukin 1 and tumor necrosis factor synthesis: effects of endogenous and exogenous glucocorticoids and the role of the pituitary-adrenal axis. Eur_i.immunol. 1989 19:301-305.

90. Zabel P, Linnemann K \& Schlaak M. Zirkadiane Rhythmik von Zytokinen. Immis.Infekt. 1993 21Suppll:38-40.

91. Michie HR. Manogue KR. Sprigg DR. Revhaugh A. O'Dwyer ST, Dinarello SA. Cerami A, Wolff SM \& Wilmore DW. Detection of circulating tumor necrosis factor after endotoxin administration. N.EnglJ.Med. 1988 318:1481-1486.

92. Michie HR, Spriggs DR, Manogue KR, Sherman ML, Revhaug A, O'Dwyer ST, Arthur K. Dinarello CA, Cerami A, Wolff SM, Kufe DW \& Wilmore DW. Tumor necrosis factor and endotoxin induce similar metabolic responses in human beings. Surgery. 1988 104:280-286.

93. Girardin E, Roux-Lombard P, Grau GE, Suter P, Gallati H, The J5 Study Group \& Dayer JM. Imbalance between tumor necrosis factor-alpha and soluble TNF receptor concentrations in severe meningococcemia. Immunol. 1992 76:20-23.

94. Brockhaus M, Schoenfeld HJ, Schlaeger EJ, Hunziker W. Lesslauer W \& Loetscher H. Identification of 2 types of tumor necrosis factor receptors on human cell lines by monoclonal antibodies. Proc.Natl.Acad.Sci.USA. 1990. 87:3127-3131.

95. Porteu F \& Nathan C. Shedding of furnor necrosis factor receptors by activated human neutrophils. J.Exp.Medi. 1990 172:599-607.

96. Lantz M, Gullberg U, Nilsson E \& Cisson I. Characterization in vitro of a human tumor necrosis factor-binding protein. A soluble fonn of a tumor necrosis factor receptor. J.Clin.Invest. 1990 86:1396-1402.

97. Seckinger P, Isaaz S \& Dayer J-M. A human inhibitor to tumor necrosis factor $\alpha$. J.Exp. Med. 1988 167:1511-1516.

98. Lantz M, Malik S. Sievin ML \& Olsson I. Infusion of tumor necrosis factor (TNF) causes an increase in circulating TNF-binding protein in humans. Cytokine. 1990 2:402406.

99. Spinas GA, Keller U \& Brockhaus M. Release of soluble receptors for tumor necrosis factor (TNF) in relation to circulating TNF during experimental endotoxinemia. J.Clin.Invest. 1992 90:533-536. 
100. Bemelmans MHA, Gouma DJ \& Buurman WA. LPS-induced sTNF receptor release in vivo in a murine model: investigation of the role of TNF, IL-1, LIF and IFN-gamma. J.Jmmunol. 1993 15!:5554-5562.

101. Pennica D, Hayflick JS, Bringman TS, Palladino MA \& Goeddel DV. Cloning and expression in Escherichia coli of the cDNA for murine tumor necrosis factor. Proc.NatlAcadSci.USA. 1985 82:6060-6064.

102. Tamatani T, Kimura S, Hashimoto T \& Onozaki K. Purification of guinea pig tumor necrosis factor (TNF): comparison of its antiproliferative and differentiative activities for myeloid leukemic cell lines with those of recombinant human TNF. J.Biochem.Tokyo. 1989 105:55-60.

103. Pauli U, Beutler B \& Peterhans E. Porcine tumor necrosis factor alpha: cloning with the polymerase chain reaction and determination of the nucleotide sequence. Gene. 1989 811:185-191.

104. Echtenacher B, Falk W, Mannel DN \& Krammer PH. Requirement of endogenous tumor nerosis factor/cachectin for recovery from experimental peritonitis. J.Imumunol. 1990 145:3762-3766.

105. Havell EA. Evidence that tumor necrosis factor has an important role in antibacterial resistance. JJmmunol. 1989 143:2894-2899.

106. Taverne J. Tavernier J. Fiers W \& Playfair JH. Recombinant tumour necrosis factor inhibits malaria parasites in vivo but not in vitro. Clin.ExpJImmunol. 1987 67:1-4.

107. Dinarello CA, Cannon JG, Wolff SM, Bernheim HA, Beutler B, Cerami A, Figari IS, Palladino Jr. MA \& O'Connor JV. Tumor necrosis factor (cachectin) is an endogenous pyrogen and induces production of interleukin 1. J.Exp.Med. 1986 163:1433-1450.

108. Nawroth PP, Bank I, Handley D, Cassimeris J, Chess L \& Stem D. Tumor necrosis factor/cachectin interacts with endothelial cell receptors to induce release of interleukin 1. J.Exp.Med. 1986 163:1363-1375.

109. Waage A \& Espevik T. Interleukin I potentiates, the lethal effect of tumor necrosis factor alpha/cachectin in mice. J.Exp.Med. 1988 167:1987-1992.

110. Leeuwenberg JF, von Asmuth EJ, Jeunhomme TM \& Buurman WA. IFN-gamma regulates the expression of the adhesion molecule ELAM-1 and IL-6 production by human endothelial cells in vitro. J.Immumol. 1990 145:2110-2114.

111. Rothstein JL \& Schreiber H. Synergy between tumor necrosis factor and bacterial products causes hemorrhagic necrosis and lethal shock in normal mice. Proc.Natl.Acad.Sci.USA. 1988 85:607-611.

112. Hsueh W, Sun X, Rioja LN \& Gonzalez Crussi $\mathbf{F}$. The role of the complement system in shock and tissue injury induced by tumour necrosis factor and endotoxin. Immunology. 1990 70:309-314.

113. Camussi G, Bussolino F, Salvidio G \& Baglioni C. Tumor necrosis factor/cachectin stimulates peritoneal macrophages, polymorphonuclear neutrophils, and vascular endothelial cells to synthesize and release platelet-activating factor, J.Exp.Med. 1987 166: 1390-1404.

114. Munker R. DiPersio 3 \& Koeffler HP. Tumor necrosis factor: receptors on hematopoietic cells. Blood. 1987 70:1730-1734.

115. Shalaby MR, Aggarwal BB, Rinderknecht E, Sverdersky LP, Finkle BS \& Palladino Jr. MA. Activation of human polymorphonuclear neutrophil function by interferon gamma and tumor necrosis factor. J.Jmmunol. 1985 135:2069-2073. 
116. Kiebanoff SJ, Vadas MA, Harlan JM, Sparks LH, Gamble JR, Agosti JM \& Waltersdorph AM. Stimulation of neutrophils by tumor necrosis factor. J.Immunol. 1986 136:4220-4225.

117. Tsujimoto M, Yokota S, Vilcek J \& Weissman G. Tumor necrosis factor provokes: superoxide anion generation from neutrophils. Biochem.Biophys.Res.Commun. 1986 137: 1094-1100.

118. Berger M, Wetzler EM \& Wallis RS. Tumor necrosis factor is the major monocyte. product that increases complement receptor expression on mature human neutrophils. Blood. 1988 71:151-158.

119. Arnaout MA. Structure and function of the leukocyte adhesion molecules CD11/CD18. Blood. 1990 75:1037-1050.

120. Hoffman $M \&$ Weinberg JB. Tumor necrosis factor $\alpha$ induces hydrogen peroxide. production and Fc receptor expression, but not increased la antigen expression by peritoneal macrophages. J.Leukocyte.Biol. 1987 42:704-707.

121. Jelinek DF \& Lipsky PE. Enhancement of human B cell proliferation and differentiation by tumor necrosis factor $-\alpha$ and interleukin 1. J.Immunol. 1987 139:2970-2976.

122. Yokota S, Geppert TD \& Lipsky PE. Enhancement of antigen- and mitogen-induced human T lymphocyte proliferation by tumor necrosis factor- $\alpha$. J Jmmunol. 1988 140:531536.

123. Leeuwenberg JFM, van Damme J, Jeunhomme GMAA \& Buurman WA. Interferon beta $\mathrm{a}_{1}$, an intermediate in the tumor necrosis factor $\boldsymbol{\alpha}$-induced increased MHC class I expressioni and an autocrine regulator of the constitutive MHC class I expression. J.Exp.Med. $1987166: 1180-1185$.

124. Sica A, Wang JM, Colota F, Dejana E, Mantovani A, Oppenheim JJ, Larsen CG, Zachariae $\mathrm{CO} \&$ Matsushima $\mathbf{K}$. Monocyte chemotactic and activating factor gene expression induced in endothelial cells by IL-1 and tumor necrosis factor. J.Immunol. 1990 144:3034- 3038.

125. Strieter RM, Kunkel SL, Showell HJ, Remick DG, Phan SH, Ward PA \& Marks RM. Endothelial cell gene expression of a neutrophil chemotactic factor by TNF-alpha, LPS, and IL-I beta. Sirience. 1989 243:1467-1469.

126. Pober JS \& Cotran RS. The role of endothelial cells in inflammation. Transplantation. 1990 50:537-544.

127. Kilbourn RG, Gross SS, Jubran A. Adarns J, Griffith OW, Levi R \& Lodato RF. NGmethyl-L-arginine inhibits tumor necrosis factor-induced hypotension: implications for the involvement of nitric oxide. Proc.Nati.Acad.Sci.USA. 1990 87:3629-3632.

128. Nawroth PP \& Stern DM. Modulation of endothelial cell hemostatic properties by tumor necrosis factor. J.Exp.Med. 1986 163:740-745 $a$.

129. van Hinsbergh VWM, Kooistra T, van den Bergh E, Princen HMG, Fiers W \& Emeis J. Tumor necrosis factor increases the production of plasminogen activator inhibitor in human endothelial cells in vitro and in rats in vivo. Blood. 1988 72:1467-1473.

130. Mestan J, Digel W, Mitmacht S, Hillen H, Blohm D, Moller A, Jacobsen H \&i Kirchner H. Antiviral effects of recombinant tumour necrosis factor in vitro. Nature. 1986 323:8168:19.

131. Wong GH \& Goeddel DV. Tunour necrosis factors alpha and beta inhibit virus replication and synergize with interferons. Nature. 1986 323:819-822.

132. Djeu JY, Blanchard DK, Halkias D \& Friedman H. Growth inhibition of Candida albicans, by human polymorphonuclear neutrophils: activation by interferon-gamma and tumor necrosis factor. J.Jmmunol. 1986 137:2980-2984. 
133. Liew FY, Parkinson C, Millott S, Severn A \& Carrier M. Tumour necrosis factor (TNF alpha) in leishmaniasis. L. TNF alpha mediates host protection against cutaneous leishmaniasis. Immunology. 1990 69:570-573.

134. Wirth JJ \& Kierszenbaum F. Recombinant tumor necrosis factor enhances macrophage destruction of Trypanosoma cruzi in the presence of bacterial endotoxin. J.Jmmunol. 1988 141:286-288.

135. Esparza L, Mannel D, Ruppel A, Falk W \& Krammer PH. Interferon gamma and lymphotoxin or tumor necrosis factor act synergistically to induce macrophage killing of tumor cells and schistosomula of Schistosoma mansoni. J.Exp.Med. 1987 166:589-594.

136. Titus RG, Sherry B \& Cerami A. Tumor necrosis factor plays a protective role in experimental murine cutaneous leishmaniasis. J.Exp.Med. 1989 170:2097-2104.

137. Neifer S, Kremsner PG \& Bienzle U. Application of anti-TNF to Plasmodium vinckeiinfected mice is followed by an increase of parasitaemia. Acta.Trop.Basel. 1989 46:273. 275.

138. Tracey KJ, Wei H, Manogue KR, Fong Y, Hesse DG, Nguyen HT, Kuo GC, Beutler B, Cotran RS, Cerami A \& Lowry SF. Cachectin/tumor necrosis factor induces cachexia, anemia, and inflammation. JExp.Med. 1988 167:1211-1227.

139. Starnes Jr HF, Warren RS, Jeevanandam M. Gabrilove J, Larchian W, Oettgen HF \& Brennan MF. Tumor necrosis factor and the acute metabolic response to tissue injury in man. J.Clin.Invest. 1988 82:1321-1325.

140. Feingold KR \& Grunfeld C. Tumor necrosis factor-alpa stimulates hepatic lipogenesis in the rat in vivo. J.Clin Invest. 1987 80:184-190.

141. Warren RS, Stames HF, Gabrilove JL, Oettgen HF \& Brennan MF. The acute metabolic efects of tumor necrosis factor administration in humans. Arch.Surg. 1987 122:1396. 1400.

142. Flores EA, Bistrian BR, Pomposelli JJ, Dinarello CA, Blackbum GL \& Istfan NW. Infusion of tumor necrosis factor/cachectin promotes muscle catabolism in the rat. A synergistic effect with interleukin 1. J.Clin.Invest. 1989 83:1614-1622.

143. Moldawer L.L, Svaninger G, Gelin J \& Lundholm KG. Interleukin 1 and tumor necrosis factor do not regulate protein balance in skeletal muscle. AmJ.Physiol. 1987 253:C766C773.

144. Darlington GJ, Wilson DR \& Lachman LB. Monocyte-conditioned medium, interleukinI and tumor necrosis factor stimulate the acute phase response in human hepatoma cells in vitro. J.Cell.Biol. 1986 103:787-793.

145. Plata-Salaman CR, Comura Y \& Kai Y. Tumor necrosis factor and interleukin-1 beta: suppression of food intake by direct action in the central nervous system. Brain.Res. 1988 448: 106-114.

146. Pang XP. Hershman JM, Mirell CJ \& Pekary AE. Impairment of hypothalamic-pituitary-thyroid function in rats ireated with human recombinant tumor necrosis factor-alpha (cachectin). Endocrinology. 1989 125:76-84.

147. Jampei HD, Duff GW, Gershon RK, Atkins E \& Durum SK. Fever and immunoregulation. III. Hyperthermia augments the primary in vitro humoral immune response. J.Exp.Med. 1983 157:1229-1238.

148. Horowitz J, Volanakis JE \& Briles DE. Blood clearance of Streptococcus pneumoniae by C-reactive protein. JImmunol. 1987 138:2598-2603.

149. Ulevitch RJ, Johnston AR \& Weinstein DB. New function for high density lipoproteins. Isolation and characterization of a bacterial lipopolysaccharide-high density lipoprotein complex formed in rabbit plasma. J.Clin.Jnvest. 1981 67:827-837. 
150. Harris HW, Grunfeld C, Feingold KR \& Rapp JH. Human very low density lipoproteins and chylomicrons can protect against endotoxin-induced death in mice. J.Clin.Invest. 1990 26:696-702.

151. Rook GAW, Taverne J \& Playfair JHL. Evaluation of TNF as antiviral, antibacterial and antiparasitic agent. Biotherapy. 1991 3:167-175.

152. Tracey KJ \& Cerami A. Pleiotropic effects of TNF in infection and neoplasia: beneficial, inflammatory, catabolic, or injurious. Immunol.Ser. 1992 56:431-452.

153. Fraker DL, Stovroff MC, Merino MJ, \& Norton JA. Tolerance to tumor necrosis factor in rats and the relationship to endotoxin tolerance and toxicity. J.Exp.Med. 1988 168:95105.

154. Tracey KJ, Morgello S, Koplin B, Fahey III TJ, Fox J, Aledo A, Manogue KR \& Cerami A. Metabolic effects of cachectin/tumor necrosis factor are modified by site of production: Cachectin/tumor necrosis factor-secreting tumor in skeletal muscle induces chronic cachexia while implantation in brain induces predominately acute anorexia. J.Clin.Invesi. 1990 86:2014-2024.

155. Mathison JC, Wolfson E \& Ulevitch R. Participation of tumor necrosis factor in the mediation of gram-negative bacterial lipopolysaccharide-induced injury in rabbits. J.Clin. Invest. 1988 81:1925-1937.

156. Ha DK, Leung SW, Fung KP. Choy YM \& Lee CY. Production of tumour necrosis factor in Listeria monocytogenes-infected animals. Int.J.Immunopharmacol. 1985 7:1-6.

157. Yamamoto A, Nagamuta M, Usami H, Sugawara Y, Watanabe N, Niitsu Y \& Urushizaki I. Release of tumor necrosis factor (TNF) into mouse peritoneal fluids by $\mathrm{OK}-432$, a streptococcal preparation. Immunopharmacology. 1986 11:79-86.

158. Debets JMH, Kampmeijer R, van der Linden MPMH, Buurman WA \& van der Linden CJ. Plasma tumor necrosis factor and mortality in critically ill septic patients. Crit.Care.Med. 1989 17:489-494.

159. Damas P, Reuter A, Gysen P, Demonty J, Lamy M \& Franchimont P. Tumor necrosis factor and interleukin-1 serum levels during severe sepsis in humans. Crit.Care.Med. 1989 17:975-978.

160. Girardin E, Grau GE, Dayer JM. Roux Lombard P \& Lambert PH. Tumor necrosis factor and interleukin-1 in the serum of children with severe infectious purpura. N.EnglJ.Med. 1988 319:397-400.

161. Cross AS,, Sadoff JC, Keliy N. Bemton E \& Gemski P. Pretreatment with recombinant murine tumor necrosis factor-alpha/cachectin and murine interleukin 1-alpha protects mice from lethal bacterial infection. J.Exp.Med. 1989 169:2021-2027.

162. Silva AT, Appelmelk BJ, Buurnan WA, Bayston KF \& Cohen J. Monoclonal antibody to endotoxin core protects mice from Escherichia coli sepsis by a mechanisrn independent of tumor necrosis factor and interleukin-6. J.Imfect.Dis. 1990 162:454-459.

163. Silva AT, Appelmelk BJ \& Cohen J. Purified monoclonal antibody to endotoxin core fails to protect mice from experimental gram-negative sepsis [letter]. J.Infect.Dis. 1993 168:256-257.

164. Lahdevirta J. Maury CP. Teppo AM \& Repo H. Elevated levels of circulating cachectin/ tumor necrosis factor in patients with acquired immunodeficiency syndrome. Ann J.Med. 1988 85:289-291.

165. Folks TM, Clouse KA, Justement J, Rabson A, Duh E, Kehrl JH \& Fauci AS. Tumor necrosis factor alpha induces expression of human immunodeficiency virus in at chronically infected T-cell clone. Proc_Natl_Acad.Sci.USA. 1989 86:2365-2368. 
166. Peterson PK, Gekker G, Chao CC, Hu SX, Bdelman C, Balfour Jr. HH \& Verhoef J. Human cytomegalovirus-stimulated peripheral blood mononuclear cells induce HIV-1 replication via a tumor necrosis factor-alpha-mediated mechanism. J.Clin.Invest. 1992 89:574-580.

167. Grunfeld C, Kotler DP, Hamadeh R, Tiemey A, Wang J \& Pierson RN. Hypertriglyceridemia in the acquired immunodeficiency syndrome. Am.J.Med. 1989 86:27-31.

168. Odeh $\mathrm{M}$. The role of tumour necrosis factor-alpha in acquired immunodeficiency syndrome. J.Intern.Med. 1990 228:549-556.

169. Grau GE, Taylor TE, Molyneux ME, Wirima J, Vassalli P, Hommel M \& Lambert PH. Tumor necrosis factor and disease severity in children with falciparum malaria. N.EnglJ. Med. 1989 320:1586-1591.

170. Scuderi P, Sterling KE, Lam KS, Finley PR, Ryan KJ, Ray CG, Petersen E, Slymen DJ \& Salmon SE. Raised serum levels of tumour necrosis factor in parasitic infections. Lancet. 1986 ii: 1364-1365.

171. Piguet PF, Grau GE, Allet B \& Vassalli P. Tumor necrosis factor/cachectin is an effector of skin and gut lesions of the acute phase of graft-vs.-host disease. J.Exp.Med. 1987 166:1280-1289.

172. Debets JMH, Leunissen KML, van Hooff HJ, van der Linden CJ \& Buurman WA. Evidence of involvement of tumor necrosis factor in adverse reactions during treatment of kidney allograft rejection with antithymocyte globulin. Transplantation. 1989 47:487. 492.

173. Saxne T, Palladino Jr. MA, Heinegard D, Talal N \& Wollheim FA. Detection of tumor necrosis factor alpha but not tumor necrosis factor beta in theumatoid arthritis synovial fluid and serum. Arthritis.Rheum. 1988 31:1041-1045.

174. Bertolini DR, Nedwin GE, Bringman TS, Smith DD \& Mundy GR. Stimulation of bone resorption and inhibition of bone formation in vitro by human tumour necrosis factors. Nature. 1986 319:516-518.

175. Saklatvala J. Tumour necrosis factor alpha stimulates resorption and inhibits synthesis of proteoglycan in cartilage. Nature. 1986 322:547-549.

176. Ruddle NH, Bergman CM, MeGrath KM, Lingenheld EG, Grunnet ML, Padula SJ \& Clark RBi. An antibody to lymphotoxin and tumor necrosis factor prevents transfer of experimental allergic encephalomyelitis. J.Exp.Med. 1990 172:1193-1200.

177. Lane JR, Neumann DA, Lafond Walker A, Herskowitz A \& Rose NR. Interleukin I or tumor necrosis factor can promote Coxsackie B3-induced myocarditis in resistant B10.A mice. J.Exp.Med. 1992 175:1123-1129.

178. Campbell IL. Iscaro A \& Harrison LC. IFN-gamma and tumor necrosis factor-alpha. Cytotoxicity to murine islets of Langerhans. J.Jmmunol. I988 141:2325-2329.

179. Oliff A, Defeo-Jones D, Boyer M, Martinez D, Kiefer D, Vuocolo G, Wolfe A \& Socher SH. Tumors secreting human TNF/cachectin induce cachexin in mice. Cell. 1987 50:555563.

180. Michie HR, Sherman ML, Spriggs DR, Rounds J, Christie M \& Wilmore DW. Chronic TNF infusion causes anorexia but not accelerated nitrogen loss. Ann.Surg. 1989 209:19-24.

181. Gutteberg TJ, Osterud B, Volden G \& Jorgensen T. The production of tumour necrosis factor, tissue thromboplastin, lactoferrin and cathepsin C during lipopolysaccharide stimulation in whole blood. ScandJ.Clin.Lab.Invest. 1990 50:421-427. 
182. Aderka D, Engeiman H, Shemer-Avni Y, Hornik V, Galil A, Sarov B \& Wallach D. Variations in serum levels of the soluble TNF receptors among healuhy individuals. $\mathbf{L y m}$ phokine.Cytokine.Res. 1992 11:157-159.

183. Balkwill F, Osborne R, Burke F, Naylor S, Talbot D, Durbin H, Tavernier J \& Fiers W. Evidence for tumour necrosis factor/cachectin production in cancer. Lancel. 1987 Ii: 12291232.

184. Jacob CO, Fronek Z, Lewis GD, Koo M, Hansen JA \& MeDevitt HO. Heritable major histocompatibility complex class II-associated differences in production of tumor necrosis factor alpha: relevance to genetic predisposition to systemic lupus erythematosus. Proc.Natl.Acad.Sci.USA. 1990 87:1233-1237.

185. Freund YR, Sgarlato G, Jacob CO, Suzuki Y \& Remington JS. Polymorphisms in the tumor necrosis factor alpha (TNF-alpha) gene correlate with murine resistance to development of toxoplasmic encephalitis and with levels of TNF-alpha MRNA in infected brain tissue. J.Exp.Med. 1992 175:683-688.

186. Miller Graziano CL, Fink M, Wu JY, Szabo G \& Kodys K. Mechanisms of altered monocyte prostaglandin E2 production in severely injured patients. Arch.Surg. 1988 123:293-299.

187. Szabo G, Miller Graziano CL. Wu JY, Takayama T \& Kodys K. Differential tumor necrosis factor production by hurnan monocyte subsets. J.Leukoc.Biol. 1990 47:206-216.

188. Luger A, Kovarik J, Stummvoll HK, Urbanska A \& Luger TA. Blood-membrane interaction in hemodialysis leads to increased cytokine production. Kidney.Int. 1987 32:84-88.

189. Henderson LW, Koch KM, Dinarello CA \& Shaldon S. Hemodialysis hypotension: The. interleukin hypothesis. Blood.Purif. 1983 1:3-8.

190. Herbelin A. Nguyen AT, Zingraff J, Urena P \& Descarnps-Latscha B. Influence of uremia and hemodialysis on circulating interleukin- $\mathbb{1}$ and tumor necrosis factor alpha. Kidney.Jnt. 1990 37:116-125.

191. Chollet-Martin S, Stamatakis G. Bailly S, Mery JP \& Gougerot-Pocidalo MA. Induction of tumour necrosis factor-alpha during haemodialysis. Influence of the membrane type. Clin.Exp Immunol. 1991 83:329-332.

192. Paydas S, Aksu HS, Paydas S, Karademir M \& Gurcay AA. Plasma levels of tumor necrosis factor alpha during hemodialysis. Nephron. 1991 57:477-478.

193. Ryan J, Beynon H, Rees AJ \& Cassidy MJD. Evaluation of the in vitro production of tumour necrosis factor by monocytes in dialysis patients. Blood.Purif. 1991 9:142-147.

194. Schaefer RM, Paczek. L. \& Heidland A. Cytokine production by monocytes during haemodialysis. Nephrol.Dial.Transplant. 19916 Suppl 2:14-17.

195. Haeffner Cavaillon N. Cavaillon M, Laude M \& Kazatchikine MD. C3a(C3adesArg) induces production and release of interleukin 1 by cultured human monocytes. J.Immunol. 1987 139:794-799.

196. Urena P, Herbelin A, Zingraff J, Lair M, Man NK, Descamps-Latscha B \& Drueke T. Permeability of cellulosic and non-cellulosic membranes to endotoxin subunits and cytokine production during in-vitro haemodialysis. Nephrol.Dial.Transplant. 1992 7:16-28.

197. Chenoweth DE, Cheung AK \& Henderson LW. Anaphylatoxin formation during hemodialysis: effects of different dialyzer membranes. Kidney.Int. 1983 24:764-769.

198. Powell AC, Bland LA, Oettinger CW, McAllister SK, Oliver JC, Arduino MJ \& Favero MS. Lack of plasma interleukin-1B or tumor necrosis factor-at elevation during unfavorable hemodialysis conditions. J.Am.Soc.Nephrol. 1991 2:1007-1013. 
199. Dinarello CA. Interleukin-1 and tumor necrosis factor and their naturally occurring antagonists during hemodialysis. Kidney.Int. 199242 Suppl:S68-S77.

200. Dyerberg J, Bang HO \& Hjome N. Fatty acid composition of the plasma lipids in Greenland Eskimos. Am.J.Clin.Nutr. 1975 28:958-966.

201. Lee TH, Hoover RL, Williams JD, Sperling RI, Ravalese III J, Spur BW, Robinson DR. Corey EJ, Lewis RA \& Austen KF. Effect of dietary enrichment with eicosapentaenoic and docosahexaenoic acids on in vitro neutrophil and monocyte leukotriene generation and neutrophil function. N.EnglJ.Med. 1985 312:1217-1224.

202. Clegg AJ. Composition and related nutritional and organoleptic aspects of palm oil. AmJ.Oil.Chemists.Soc. 1973 50:321-324.

203. Pereira TA, Sinniah R \& Das NP. Effect of dietary palm oil on lipoprotein lipases: lipoprotein levels and tissue lipids in rat. Biochem.Med.Metab.Biol. 1990 44:207-217.

204. Pereira TA, Shahi GS \& Das NP. Effects of dietary palm oil on serum lipid peroxidation, antithrombin III, plasma cyclic AMP, and platelet aggregation. Biochem.Med.Metab.Biol. 1991 45:326-332.

205. Sundram K, Khor HT, Ong AS \& Pathmanathan R. Effect of dietary palm oils on mammary carcinogenesis in female rats induced by 7,12-dimethylbenz(a)anthracene. Cancer Res. 1989 49:1447-1451.

206. Goetzl EJ. Vitamin E modulates the lipoxygenation of arachidonic acid in leukocytes. Nature. 1980 288:183-185.

207. Cannon JG, Meydani SN, Fielding RA, Fiatarone MA, Meydani M, Farhangmehr M, Orencole SF, Blumberg JB \& Evans WJ. Acute phase response in exercise. II. Associations between vitamin E, cytokines, and muscle proteolysis. Am.J.Physiol. 1991 260(6Pt2):R1235-R1240.

208. Nutrition and health aspects of palm oil. PORIM International Development conference. 5-9 september 1989 Abstract Book.

209. MeManus LM, Hahahan DJ, Demopoulos CA \& Pinckard RN. Pathobiology of the intravenous infusion of acetyl glyceryl ether phosphorylcholine (AGEPC), a synthetic platelet-activating factor (PAF), in the rabbit. JImmunol. 1980 124:2919-2923.

210. Bessin P, Bonnet J, Apffel D, Soulard C, Desgroux L, Pelas I \& Benveniste J. Acute circulatory collapse caused by platelet-activating factor (PAF-acether) in dogs. EurJ.Pharmacol. 1983 86:403-413.

211. Terashita Z, Imura Y, Nishikawa X \& Sumida S. Is platelet activating factor (PAF) mediator of endotoxin shock? Eur J Pharmacol. 1985 109.257-261.

212. Helle M, Brakenhoff JP, De Groce ER \& Aarden LA. Interleukin 6 is involved in interleukin 1-induced activities. Eur.J.Jmmunol. 1988 18:957-959.

213. Geiger T, Andus T, Klapproth J, Hirano T, Kishimoto T \& Heinrich PC. Induction of rat acute-phase proteins by interleukin 6 in vivo. Eur J Jmmunol. 1988 18:717-721.

214. Klosterhalfen B, Horstmann Jungemann K, Vogel P, Flohe S, Offner F, Kirkpatrick CJ \& Heinrich PC. Time course of various inflammatory mediators during recurrent endotoxemia. Biochem.Pharmacol. 1992 43:2103-2109.

215. Chang SW, Feddersen CO. Henson PM \& Voelkel NF. Platelet-activating factor mediates hemodynamic changes and lung injury in endotoxin-treated rats. J.Clin.Invest. 1987 79:1498-1509.

216. Heremans H, Dillen C. Put W, Van Damme J \& Billiau A. Protective effect of antiinterleukin (IL)-6 antibody against endotoxin, associated with paradoxally increased IL-6 levels. Eur J.Immunol. 1992 22:2395-2401. 
217. Van Damme J, Opdenakker G, Simpson RJ, Rubira MR, Cayphas S, Vink A, Billiau A \& Van Snick J. Identification of the human $26-\mathrm{kD}$ protein, interferon beta 2 (IFN-beta 2), as a $\mathbf{B}$ cell hybridorna/plasmacytoma growth factor induced by interleukin 1 and tumor necrosis factor, J.Exp.Med. 1987 165:9!4-919.

218. Jirik FR, Podor TJ, Hirano T, Kishimoto T, Loskutoff DJ, Carson DA \& Lotz M. Bacterial lipopolysaccharide and inflammatory mediators augment IL-6 secretion by human endothelial cells. I.Immunol. 1989 142:144-147.

219. Jablons DM, Mule JJ, MeIntosh JK, Sehgal PB, May LT, Huang CM, Rosenberg SA \& Lotze MT. IL-6/IFN-beta-2 as a circulating hormone. Induction by cytokine administration in humans. J.Immunol'. 1989 142:1542-1547.

220. Ruis NM, Rose JK \& Valone FH. Tumor necrosis factor release by human monocytes stimulated with platelet activating factor. Lipids. 1991 26:1060-1064.

221. Heflin AC \& Brigham KL. Prevention by granulocyte depletion of increased vascular permeability of sheep lung following endotoxemia. J.Clin.Invest. 1981 68:1253-1260.

222. Meyrick B \& Brigham KL. Acute effects of Escherichia coli endotoxin on the pulmonary microcirculation of anesthetized sheep structure: function relationships. Lab.Invest. 1983 48:458-470.

223. Bevilacqua M, Butcher E, Furie B, Furie. B, Gallatin M, Gimbrone M, Harlan J, Kishimoto K, Lasky L, McEver R, Paulson J, Rosen S, Seed B, Siegelman M, Springer T. Stcollman L. Tedder T, Varki A, Wagner D, Weissman I \& Zimmerman G. Selectins: a family of adhesion receptors [letter]. Cell, 1991 67:233.

224. Bevilcqua MP, Pober JS, Mendrick DL, Cotran RZ \& Gimbrone MA. Identification of an inducable endothelial leukocyte adhesion molecule. Proc.Natl.Acad.Sci.USA. 198784 : 9238-9242.

225. Leeuwenberg JF, Jeunhomme TM \& Buurman WA. Induction of an activation antigen on human endothelial cells in vitro. Eur J.Immunol. 1989 19:715-720.

226. Leeuwenterg JFM, Jeunhomme GMAA \& Buuman WA. Adhesion of polymorphonuclear cells to human endothelial cells. Adhesion molecule dependent, and Fc receptormediated adhesion-molecule-independent mechanisms. Clin.Exp.Immunol. 1990 81:496500.

227. Munro JM, Pober JS, Cotran RS. Recruitment of neutrophils in the local endotoxin response: association with de novo endothelial expression of endothelial leukocyte adhesion molecule-1. Lab.Invest. 1991 64:295-299.

228. Munro JM, Pober JS \& Cotran RS. Tumor necrosis factor and interferon-gamma induce distinct patterns of endothelial activation and associated leukocyte accumulation in skin. of Papio anubis. AmJ.Parhol. 1989 135:121-133.

229. Cotran RS, Gimbrone Jr MA, Bevilacqua MP. Mendrick DL \& Pober JS, Induction and detection of a human endothelial activation antigen in vivo. JExp.Med. 1986 164:661-666.

230. Redi H, Dinges HP, Buurman WA, van der Linden CJ, Pober JS, Cotran RS \& Schlag G. Expression of endothelial leukocyte adhesion molecule-I in septic but not traumatic/ hypovolemic shock in the baboon. AmJ.Pathol. 1991 139:461-466.

231. Redl H, Schlag G, Kneidinger R, Dinges HP \& Davies J. Activation/adherence phenomena of leukocytes and endothelial cells in trauma and sepsis. In: Schlag $G$ \& Redl $\boldsymbol{H}$. (eds) Pathophysiology of shock, sepsis, and organ failure. Springer Verlag, Berlin. 1993: 549-563.

232. Gundel RH, Wegner CD, Torcellini CA, Clarke CC, Haynes N, Rothlein R, Smith CW \& Letts LG. Endothelial leukocyte adhesion molecule-1 mediates antigen-induced acute 
airway inflammation and late-phase airway obstruction in monkeys. J.Clin.Invest. 1991 88:1407-1411.

233. Mulligan MS, Varani J, Dame MK, Lane CL, Smith CW, Anderson DC \& Wand PA. Role of endothelial-leukocyte adhesion molecule I (ELAM-1) in neutrophil-mediated lung injury in rats. J.Clin.Jnvest. 1991 88:1396-1406.

234. Warren JS, Yabroff KR, Remick DG, Kunkel SL, Chensue SW, Kunkel RG, Johnson KJ \& Ward PA. Tumor necrosis factor participates in the pathogenesis of acute immune complex alveolitis in the rat. J.Clin.Invest. 1989 84:1873-1882.

235. Angehm P, Banner D, Braun T, d'Arcy A, Gehr G, Gentz R, Mackay F, Schlaeger E-J. Schoenfeld H. Loetscher H \& Lesslauer W. Two distinct tumor necrosis factor receptors in health and disease. In: Fiers W \& Bumman WA. (eds) Tumor necrosis factor: molecular and cellular biology and clinical relevance. S. Karger AG. 1993:33-39.

236. Aggarwal BB, Traquina PR, \& Eessalu TE. Modulation of receptors and cytotoxic response of tumor necrosis factor- $\alpha$ by various lectins. J.Biol.Chem. 1986 261:1365213656.

237. Hepbum A, Demolle D, Boeynaems JM, Fiers W \& Dumont JE. Rapid phosphorylation of a $27 \mathrm{kDa}$ protein induced by tumor necrosis factor. FEBS.Lett. 1988 277:175-178.

238. Schütze S, Berkovic D. Tomsing O, Unger C \& Krönke M. Tumor necrosis factor induces rapid production of 1'2'diacylglycerol by a phosphatidyl choline-specific phospholipase C. J.Exp.Med. 1992 174:975-988.

239. Schulze-Osthoff K, Bakker AC, Vanhaesebroeck B, Beyaert R, Jacob WA \& Fiers W. Cytotoxic activity of tumor necrosis factor is mediated by early damage of mitochondrial functions. Evidence for the involvement of mitochondrial radical formation. J.Biol.Chem. 1992 267:5317-5323.

240. Ruff MR \& Gifford GE. Tumor necrosis factor. Lymphokines. 1981 2:235-272.

241. Fiers $\mathbf{W}$. Tumor necrosis factor. Characterization at the molecular, cellular and in vivo level. (Review). FEBS.Lett. 285:199-212.

242. Takahashi N, Brouckaert P \& Fiers W. Induction of tolerance allows separation of lethal and antitumor activities of tumor necrosis factor in mice. Cancer.Res. 1991 51:23662372.

243. Mosselmans R, Hepbum A, Dumont JE, Fiers W \& Galand P. Endocytic pathway of recombinant murine tumor necrosis factor in L-929 cells. J.Immunol. 1988 141:30963100 ,

244. Ding AH, Porteu F, Sanchez E \& Nathan CF. Downregulation of tumor necrosis factor receptors on macrophages and endothelial cells by microtubule depolymerizing agents. J.Exp.Med. 1990 171:715-727. 



\section{SUMMARY OF THE THESIS}

Septic shock is a serious disease state which accounts for the majority of death in the intensive care unit. The syndrome is characterized by either fever or hypothermia, hematological changes, hemodynamic instability and tissue injury which leads to respiratory and renal failure. Septic shock has traditionally been considered to be caused by the presence of microorganisms in the blood stream. But despite availability of modern antibiotics, survival rate does not improve. Mortality from sepsis seems to be mainly dependent on the unpredictable occurrence of complications such as shock and organ failure and not on the underlying disease. It is now becoming more and more clear that it is not the invading microorganism which determines the occurrence of shock and tissue injury during sepsis, but rather the excessive production of a cascade of endogenous inflammatory humoral mediators, named cytokines. This same mechanism of deranged cytokine production is considered to be involved in the systemic inflammatory response syndrome which can accompany non-infectious diseases. Considerable evidence has been obtained that TNF has a central position in the cytokine cascade during systemic inflammation, but defining its exact biological role appeared to be very difficult. In this thesis, several aspects of TNF with regard to its detection, production and its relation to other humoral inflammatory mediators during the systemic inflammatory response syndrome have been studied.

In Study 1, the most optimal procedure for the measurement of biologically active human TNF in plasma has been determined. $t t$ is shown that false positive and false negative results can be a consequence of improper handling of blood samples. This can be prevented by sampling blood in an EDTA-containing system and separating bloodcells from plasma within 15 minutes after blood collection. It has further been shown that measurement of biologically active human TNF can be performed in a sensitive and reliable way with the sandwich TNF ELISA used throughout this thesis.

In Study 2, it has been demonstrated that, whereas some sandwich immunoassays for TNF recognize biologically active unbound TNF, other immunoassays of similar type also detect biologically inactive TNF/TNF receptor complexes. Competitive immunoassays for TNF even give a positive signal in the presence of free soluble TNF receptors, which implicates that this type of immunoassay is unfit for the measurement of TNF in biological fluids. Many reports which demonstrate the presence of circulating TNF in septic patients are based on immunoassays which, besides detecting biologically active free TNF, also give positive results on either free soluble TNF receptors or soluble TNF receptors which are occupied with TNF. Reevaluation of published data, with the consideration that only part of the immunoassays are specific for free TNF, shows that biologically active TNF is not consistently present in the circulation of septic 
patients. It may be that excessive tissue levels of TNF are the cause of tissue damage and circulating free TNF reflects the leakage of local overproduction of TNF.

Studies 3 and 4 contain results from experiments which investigate the variability of TNF responsiveness. It has been theorized that TNF responses variably, in order to explain the biological variation in risk and severity of immuno-inflammatory diseases. Results presented in Study 3 demonstrate that hemodialysis induces within 15 minutes a transient reduction of in vitro TNF and IL 6 responsiveness by peripheral blood monocytes. It has subsequently been shown that this reduction does not occur during ex vivo dialysis. These discrepant results can be explained by the assumption that a high responsive subpopulation of monocytes exists, which, during in vivo dialysis, is preferentially entrapped in the microcirculation after membrane activation.

The influence of palm oil consumption on cytokine responsiveness has been investigated in Study 4. The results suggest that substitution of dietary fat by palm oil reduces the tendency of peripheral blood monocytes to secrete TNF in vitro. IL-6 and IL-8 secretion are not affected by palm oil consumption. Significant effects of palm oil consumption have also been reported on serum lipid profile and coagulation parameters. Several lines of evidence point to the importance of the Vitarnin E constituent of palm oil for its biological effects.

In studies 5, 6 and 7, several inflammatory messenger events which occur during the systemic inflammatory response in animal models and in patients have been investigated. In Study 5, the interrelationship between the humoral inflammatory mediators TNF, IL-6 and PAF, which all contribute to the pathogenesis of septic shock, has been investigated in mice. It is shown that TNF induces the release of IL-6 during LPS-induced shock in mice which illustrates the function of TNF as a motor of the cytokine cascade. This specific feature of TNF is considered to contribute to the diversity of the TNF effects. The experiments further demonstrate that PAF is a trigger for TNF release in vitro. In vivo, however, PAF is shown not to be essential for a maximal TNF response. These results demonstrate the flexibility of the mechanism of TNF induction, with the apparent goal of an intact TNF response during severe inflammation in vivo.

Study 6, describes tissue expression of E-selectin, an adhesion molecule for neutrophils, in a monkey model for septic shock. It is observed that E-selectin expression is newly induced on the vascular endothelium of almost every organ, with preference for lung tissue and skin, in septic monkeys. The pronounced E-selectin expression on the endothelium of the lung is considered to reflect the inflammatory reaction which underlies ARDS. The functional role of E-selectin in inducing tissue damage, for which tissue-infiltration of neutrophils is important, remains to be elucidated.

In Study 7, the clinical relevance of the results obtained in Study 6 has been investigated. This study describes the E-selectin expression in skin biopsies from patients suffering from systemic inflammation due to severe peritonitis. It is shown that, although the 
primary site of inflammation was the peritoneum, de novo E-selectin expression is induced on the vasculature of the skin in these patients. It may be that agents which are able to induce E-selectin, such as LPS or TNF, are released from the locus of inflammation and activate endothelial cells in remote skin. A number of additional observations demonstrate the involvement of TNF in the induction of E-selectin expression during systemic inflammation.

Finally, in Study 8, the relation between TNF-receptor trigger duration and effect has been investigated. The results demonstrate that both for TNF-induced cytotoxicity on L929 cells and for TNF-induced E-selectin expression on human endothelial cells, a prolonged interaction for hours between TNF and the membrane receptor for TNF is needed to reach maximal effect. This typical feature of TNF may appear to be crucial for the intent to interfere with the pathological consequences of a sustained excessive release of TNF during sepsis. 


\section{SAMENVATTING VAN HET PROEFSCHRIFT}

Septische shock is een emstige aandoening, die momenteel de belangrijkste doodsoorzaak is in de chirurgische intensive carc. De ziekte kenmerkt zich door een gestoorde regulatie van de lichaamstemperatuur, hematologische veranderingen, hemodynamische instabiliteit en weefselschade met als gevolg ademhalingsstoomissen en nierinsufficientie. Aanvankelijk werd de aanwezigheid van microorganismen in de bloedbaan aangewezen als directe oorzaak voor septische shock. Maar het gebruik van modeme antibiotica heeft de mortaliteit ten gevolge van sepsis niet kunnen verminderen. Sterfte door sepsis lijkt eerder samen te hangen met het min of meer onvoorspelbare optreden van shock en orgaanfalen dan met de oorzakelijke aandoening. Het wordt nu steeds duidelijker dat de ongecontroleerde produktie van endogene cytokines de directe aanleiding is tot shock en weefselschade en niet het ocrzakelijke microorganisme. Ditzelfde mechanisme lijkt ten grondslag te liggen aan de gegeneraliseende entstekingsreactie die als complicatie kan optreden bij niet-infectieuze ziekten. TNF lijkt een centrale rol te spelen binnen de cytokine cascade. Tot nu toe is het echter nog niet mogelijk geweest om de precieze rol van TNF tijdens sepsis te identificeren. In dit proefschrift worden een aantal aspecten van TNF met betrekking tot detectie, produktie en de relatie tot andere ontstekingsmediatoren tijdens de gegeneraliseerde ontstekingsreactie bestudeend.

In Studie I word de techniek van de plasma TNF bepaling geoptimaliseerd. Aangetoond wordt hoe men door verkeerde bloedafname procedures, vals positieve of vals negatieve TNF waarden kan veroorzaken. Door een EDTA afname systeem te kiezen en het plasma binnen 15 minuten van de bloedcellen te scheiden kan dit voorkomen worden. Vervolgens wordt aangetoond dat de sandwich ELISA voor humaan TNF die gebruilkt wordt in de studies voor dit proefschrift, geschikt is orn op gevoelige en betrouwbare manier de hoeveelheid biologisch actief TNF te meten.

In Studie $\mathbf{2}$ wordt aangetoond dat sommige sandwich immunoassays voor TNF alleen biologisch actief vrij TNF herkennen, terwiil andere immunoassays van hetzelfde type ook biologisch niet actieve TNF/INF receptor complexen detecteren. Competitieve immunoassays, voor TNF herkennen zelfs onbezette soluble TNF receptoren als zou dit TNF zijn. Deze eigenschap maakt dit type immunoassay ongeschikt voor de meting van TNF in lichaamsvloeistoffen. Vele publikaties die de anwezigheid van TNF in de circulatie văi septische patiënten rapporteren, baseren zich op TNF assays die meer herkennen dan alleen ongebonden en biologisch actief TNF. Wanneer de in het verleden gepubliceerde resultaten opnieuw getvalueend worden, met de overweging dat slechts een deel van de TNF assays daadwerkelijk biologisch actief antigeen detecteert, dan blijkt de aanwezigheid van biologisch actief vrij TNF in het bloed van septische patiënten zeker geen consistente bevinding te zijn. Mogelijk is de aanwezigheid van TNF 
in de weefsels pathofysiologisch relevant en is circulerend TNF de weerslag van een lokaal niet wegvangbare hoeveelheid TNF.

Studies 3 en 4 beschrijven onderzoek naar het bestaan van een biologische variatie in de TNF secretie. Er wordt verondersteld dat de cytokine respons beïnvloedbaar is, om zo de variatie die bestaat tussen verschillende patiënten populaties in risico en emst van infektieuze en immunologische aandoeningen te verklaren. De resultaten van de derde studie tonen aan dat hemodialyse de cytokine respons beïnvloedt. Gedurende standaard hemodialyse blijkt de in vitro TNF en IL 6 release tijdelijk onderdrukt te zijn. Maar wanneer dezelfde metingen tijdens een ex vivo dialyse worden verricht, wordt dit effect nief teruggevonden. Deze discrepantie zou verklaard kunnen worden door aan te nemen dat een hyperreactieve subpopulatie van monocyten bestaat, die na membraan-activatie preferen-tieel wordt weggevangen in de microcirculatie van de patiënt.

In Studie $\mathbf{4}$ is de invloed van substitutie van het dieetvet door palmolie op de cytokine respons gemeten. De relatieve TNF respons lijkt afgenomen te zijn tijdens een dergelijk dieet. De IL-6 en IL-8 respons blijven echter onveranderd. Ook zijn, door anderen, invloeden van palmolie consurnptie op de serum vetzuur status en de bloedstolling gerapporteerd. Er bestaan meerdere aanwijzingen dat het Vitamine $\mathrm{E}$ bestanddeel de uiteindelijke corzaak is van de waargenomen biologische effecten van palmolie.

De Studies 5, 6 en 7 beschrijven een aantal aspecten van de humorale communicatie tijdens een gegeneraliseerde ontstekingsreactie in diermodellen en bij patiënten. In Studie 5 wordt de samenhang onderzocht tussen TNF, IL-6 en PAF secretie in een in vivo en een in vitro muizenmodel voor LPS geïnduceerde cytokine release. Deze drie ontstekingsmediatoren dragen alle bij aan de pathogenese van septische shock. De resultaten tonen aan dat TNF de secretie van IL-6 induceert, hetgeen de functie van TNF als motor achter de cytokine cascade illustreert. Er wordt verondersteld dat deze eigenschap van TNF ten grondslag ligt aan de grote diversiteit van de door TNF geïnduceerde effecten. De experimenten laten vervolgens zien dat PAF een trigger is voor TNF release in vitro. In vivo blijkt PAF echter niet essentieel voor een maximale TNF respons. Deze resultaten illustreren het aanpassingsvermogen van het mechanisme dat TNF release induceert, met het kennelijke doel om ondanks suboptimale omstandigheden een maximale TNF respons te waartorgen.

In Studie 6 wordt de weefselexpressie van een adherentie molecule voor neutrofiele granulocyten, E-selectin, in een apenrnodel voor septische shock bestudeerd. Hieruit blijkl dat in bijna ieder orgaan een de novo vasculaire expressie van het E-selectin melecule wordt geînduceerd, met narne in de long en in de huid. De sterke expressie op de vaten in de long zou een weerslag kunnen zijn van het ontstekingsproces dat aanleiding geeft tot ARDS. Hoewel de emst van de weefselschade tijdens septische shock samenhangt met de hoeveelheid weefsel infiltrerende granulocyten, is het nog niet aangetoond of de E-selectin expressie tijdens sepsis ook van functioneel belang is voor het optreden van orgaanfalen. 
In Studie 7 wordt het klinisch belang van de zesde studie onderzocht. Hierin wordt de E-selectin expressie gemeten in huid biopsietn van patiēnten met gegeneraliseerde ontsteking op basis van peritonitis. Hoewel bij deze patiénten de primaire plaats van ontsteking het peritoneum is, wordt in de huid nieuw geìndiceerde E-selectin expressie aangetoond. Het is mogelijk dat ter plaatse van het ontstoken peritoneum, stoffen vrijkomen die in staat zijn E-selectin expressie te induceren, die dit vervolgens op afstand doen. Er worden meerdere waarnemingen beschreven die het belang van TNF voor de E-selectin inductie tijdens sepsis aantonen.

Tot slot wordt in Studie 8 de verhouding tussen de duur van de stimulatie van de TNF receptor en het biologische effect van TNF beschreven. De resultaten laten zien dat voor zowel de cytotoxiciteit van TNF op L929 cellen als voor TNF geìnduceerde E-selectin expressie op humane endotheelcellen, een langdurige interactie tussen TNF en de membraan receptor van meerdere uren nodig is om een optimaal effect van TNF to bewerkstelligen. Deze opvallende eigenschap zou van cruciaal belang kunnen blijken te zijn bij onze pogingen om met behulp van TNF-bindende stoffen te interveniëren in de vernietigende stroom van gebeurtenissen gedurende sepsis. 



\title{
LIST OF PUBLICATIONS UNDERLYING THIS THESIS
}

\author{
Study 1 \\ Evaluation of measurement of human TNF in plasma by ELISA. Engelberts I, Moller A, Schoen \\ GJM, van der Linden CJ \& Buurman WA. Lymphokine.Cytokine Res. 1991 10:69-76.
}

\section{Study 2}

Evidence for different effects of soluble TNF-receptors on various TNF measurements in human biological fluids. Engelberts I. Stephens S, Francot GJM, van der Linden CJ \& Buurman WA. Lancet. 1991 338:515-516 (Letter).

\section{Study 3}

The effect of hemodialysis on peripheral blood monocyte TNF $\alpha$, IL- 6 and IL -8 secretion in vitro. Engelberts L. Francot GJM, Leunissen KML, Haenen B, Ceska M, van der Linden CJ \& Buurman WA. Nephron. 1993 66:396-403.

\section{Study 4}

The effect of replacement of dietary fat by palm oil on in vitro cytokine release. Engelberts I, Sundram K, van Houwelingen AC, Hornstra G, Kester ADM, Ceska M. Francot GJM, van der Linden CJ \& Buurman WA. BrJINutr, 1993 69:159-167.

\section{Study 5}

The interrelation between TNF, IL-6, and PAF secretion induced by LPS in an in vivo and in vitro murine model. Engelberts 1, von Asmuth EJU, van der Linden CJ \& Buurman WA. Lymphokine.Cytokine.Res. 1991 10:127-131.

\section{Study 6}

A role for ELAM-1 in the pathogenesis of MOF during septic shock. Engelberts L, Samyo SK. Leeuwenberg JFM, van der Linden CJ \& Buuman WA. J.Surg.Res. 1992 53:136-144.

\section{Study 7}

Generalized inflammation during peritonitis evidenced by intracutaneous E-selectin expression. Engelberts I, van Hoof SCJ, Samyo SK, Buurman WA \& van der Linden CJ. Clin.Immunol.Immunopathol. 1992 65:330-334.

\section{Study 8}

Administration of TNF $\alpha$ inhibitors after exposure to TNFa prevents development of maximal biological effect; an argument for clinical treatment with TNF $\alpha$ inhibitors. Engelberts I. Moller A, Leeuwenberg JFM, van der Linden CJ \& Buurman WA. J.Surg. Res. 1992 53:510514. 


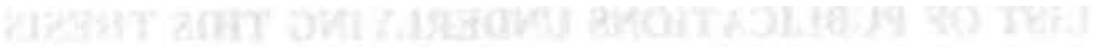

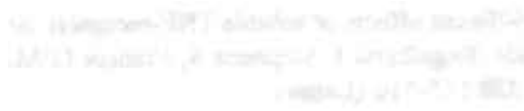




\section{DANKWOORD}

Bij het zien van een foto met een stralende bergbeklimmer op de zojuist met moeite bereikte bergtop, zal het niet moeilijk zijn de vreugde en trots van deze avonturier mee te voelen. Een iets nauwkeuriger bekijken van de afbeelding laat ons wellicht de vermoeidheid van het gezicht van de alpinist aflezen. Maar de foto vertelt ons niets over de specifieke problemen die moesten worden opgelost om de top te bereiken. Evenmin doet zo'n foto recht aan de vele gidsen en dragers, zonder wie de gelukkige nooit een dergelijke prestatie had kunnen leveren. Of de berg nu vanaf de noord-, of de zuidkant beklommen werd en of de klimmer daarbij veel of weinig hulp kreeg, de informatic op de foto blijft gelijk. Maar juist de lessen onderweg naar de top zullen het gemak bepalen waarmee een eventuele volgende expeditie ondernomen zal kunnen worden.

Evenzo biedt een proefschrift ruim zicht op het behaalde resultaat na jaren experimenteren, getallen bewerken en teksten schrijven. De blijdschap en de trots van de promovendus zijn daaruit eenvoudig af te leiden. De lezer kan zich echter onmogelijk een voorstelling maken van de verschillende hindernissen en omwegen die genomen werden voor het proefschrift werd geschreven. Terwijl dus juist deze ervaringen groeifactor zijn voor de ziel; niet de korte glans die ondervonden wordt na de verdediging van het proefschrift. Daarom wil ik op deze plaats al mijn expeditiegenoten die het mij mogelijk maakten een boeiende weg af te leggen en de top te bereiken, van harte bedanken.

Mijn promotor, Prof. Dr. Gauke Kootstra, dank ik voor de juiste omstandigheden die hij wist te creëren waarin ik de experimenten kon doen en de begeleiding kon krijgen die nodig waren voor de totstandkoming van dit proefschrift.

Mijn tweede promotor, Prof. Dr. Cees van der Linden dank ik, omdat hij met zijn heldere kritiek tè voortvarende hypothesen vaak tijdig wist te ontmantelen, maar ook nog onvolgroeide waardevolle ideeên tot iets toetsbaars dwong. Cees, ik wenste dat ik evenzoveel kritiek van jou kon krijgen op mijn klinische werk.

Wim Buunnan, als co-promotor heb je met heel veel overgave mij de weg gewezen. Het gebied waardoor ik met moeite mijn weg zocht, ken jij als je broekzak. De richting die je me aangaf was vaak een andere dan die ik mij had voorgesteld. Maar door het volgen van jouw pad heb ik veel uitzichten gezien die ik zonder jou zeker had moeten missen.

Eckhardt von Asmuth, jouw bijdrage aan de uiteindelijk gekozen route is aanzienlijk. Jij stond er niet alleen om mij de weg aan te wijzen. Nog vaker wist je op het juiste moment de handen in je zakken te houden, zodat ik leerde met zelfvertrouwen een eigen richting in te slaan.

Gaby Francot, op een nauwgezette manier heb je een belangrijk deel van de gegevens verzameld die de basis vormen van dit proefschrift. Niet alleen de droge resultaten van de experimenten, maar vooral jouw eigen slimme interpretatie daarvan ieverden vaak een opstap voor volgende experimenten. 
Mariélle van der Linden, voor de komst van Gaby hielp jij mij bij de uitvoering van de enorme hoeveelheden ELISA's en kweekwerk. Maar mijn meest levendige herinneringen zijn toch meer aan onze lange wandelingen samen dan aan jouw werk op het lab.

Jet, Maarten, Marc en Mieke, jullie niet aflatende belangstelling en discussies tijdens de werkbesprekingen of gedurende het verorberen van een ongelofelijke hoeveelheid vlaaien, leverden een goede bodem voor het laten gedijen van nieuwe ideeën. Trudy en Ilse, jullie sluitende schema's zorgden ervoor dai de stikstofvaten en de kweekstoof altijd gevuld bleven. Zo hoefde geen van onze unieke cellijnen het met de dood te bekopen. Albert, Stephen en Sigrid, jullie hielpen mij bij het op de meest onmogelijke tijden verkrijgen van patiënten -, of proefdier materiaal. Van alles waarover ik dankzij jullie kon beschikken, kan minstens nòg een proefschrift geschreven worden.

Sue Stephens, your enthousiasm was inspiring when we together, the sea being between us, developed our theory on soluble TNF receptors. Mick Deutz, jij wist well altijd de juiste functie toetsen te vinden als ik weer tevergeefs probeerde een onwillige computer in het gareel te krijgen. De grote kennis van hemodialyse en het lopende onderzoek daarover van Karel Leunissen maakten de publikatie mogelijk van de cytokine metingen tijdens nierdialyse. Rian van Houwelingen en Gerard Homstra organiseerden zorgvuldig de palmolie studie. Daama stonden zij mij een deel van hun waardevolle proefmateriaal af. Arnold Kester ordende de berg resultaten die dit opleverde.

Prof. Dr. Wouters, Prof. Dr. Goris, Prof. Dr. van Hooff, Prof. Dr. de Lange en Prof. Dr. Thijs dank ik voor hun bereidheid het manuscript te willen beoordelen.

De verpleegkundigen van de intensive care afdeling en de afdeling hemodialyse van het AZM gaven mij altijd de ruimte om mijn metingen aan de patiënten te doen. Maar zonder de hartelijke toestemming van de patiënten dat hun weefsels naar het biomedisch centrum gingen in plaats van naar het klinisch chemisch lab, had ik dit proefschrift niet kunnen schrijven.

De gastvrijheid van Corrie Stada veranderde mijn verhuizing van Rotterdam naar Maastricht in een vrolijke periode. En Jan, Greetje, Vincent en Marieke Lansbergen, jullie gunden mij een plek in jullie huis toen mijn onderzoekersbestaan verzwaard werd met een stuk gips. Samen met Paul, Gaby. Eckhardt en Iris hebben jullie mij door een paar moeilijke maanden heen geholpen. Dank jullie wel.

Tenslotte mijn ouders, pap en mam, jullie vertrouwen en relativeringsvermogen deden me vaak de pen weer oppakken op momenten waarop ik bijna de moed had opgegeven. De PTT krijgt een belangrijke klant minder als het er een keer op zit. 
Voor geesters is wat was en weren anal is.

2i) grijpen gisteren, heden en mongen samen met dèn blikc, evenals men zonder spellen een woond leest.

Multatiali)

\section{CURRICULUM VITAE}

Ingeborg Engelberts was born on the 31st of may, 1963 in The Hague, The Netherlands. She passed the high school examination in 1981 (OVWO). She started her medical study in 1981, at the Erasmus University of Rotterdam and graduated cum laude in 1988.

From January 1984 to June 1984 she was a student researcher at the Department of Pathology at the Erasmus University in Rotterdam. Between October 1984 and October 1986 she performed research at the Department of Radiology of the Erasmus University in Rotterdam. From August 1988 to December 1988, she worked as a resident at the department of surgery at Schieland Ziekenhuis in Schiedam. Between January 1989 and June 1991 she was research fellow at the laboratory of the Department of Surgery at the University of Limburg in Maastricht. At July 1991 she started her surgical residency at the surgical department of the Academic Hospital in Mastricht, where she started her training in general surgery at January 1992.

At November 1991, she was awarded the SWOAHS Prize for best oral presentation at the 4th SEOHS symposium for experimental research in surgery. 
$(4)$

4. $1=02$

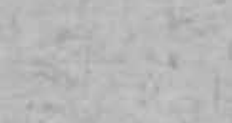

$x_{1}^{2}$

2it.

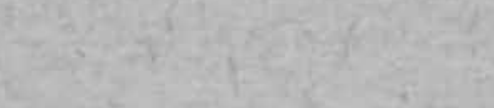

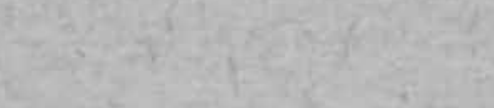

and 